\title{
Exploration in North-West Mongolia and Dzungaria
}

\section{Author(s): Douglas Carruthers}

Source: The Geographical Journal, Vol. 39, No. 6 (Jun., 1912), pp. 521-551

Published by: geographicalj

Stable URL: http://www.jstor.org/stable/1778190

Accessed: 05-05-2016 02:24 UTC

\section{Your use of the JSTOR archive indicates your acceptance of the Terms \& Conditions of Use, available at}

http://about.jstor.org/terms

JSTOR is a not-for-profit service that helps scholars, researchers, and students discover, use, and build upon a wide range of content in a trusted digital archive. We use information technology and tools to increase productivity and facilitate new forms of scholarship. For more information about JSTOR, please contact support@jstor.org.

The Royal Geographical Society (with the Institute of British Geographers), Wiley are collaborating with JSTOR to digitize, preserve and extend access to The Geographical Journal 


\section{The \\ Geographical Journal.}

No. 6.

JUNE, 1912.

Vot. XXXIX.

\section{EXPLORATION IN NORTH-WEST MONGOLIA AND DZUNGARIA.*}

By DOUGLAS CARRUTHERS.

THE exploration of Mongolia has been almost entirely monopolized by the Russians. The great unknown that lay beyond their Siberian frontier fifty years ago was a "loadstar" to the Russian pioneers, who were for ever pushing on from their newly acquired territory into what, they thought, might be richer lands. Thus, the wide Mongolian platean and Dzungarian steppes were explored by men chiefly of Russian nationality. In consequence, there is, perhaps, no country in the world on which there is so little information in the English language as Mongolia and Dzungaria.

The mysterious and almost incredible wanderings of Atkinson published in 1858-60 (whose unsatisfactory accounts are almost impossible to follow), the journeys of Ney Elias in 1872-3, and Younghusband in 1887, give us the sum total of our knowledge of things Mongolian in the English language. In the Yenisei basin we had no forerunners, and in Dzungaria but one, Etherton, who, in 1909, rode from Kalja to Tulta in the

* Royal Geographical Society, March 25, 1912. Map, p. 640. The journey which is here described was undertaken by Mr. J. H. Miller, Mr. M. P. Price, and myself in the years 1910-11. Notice of it appeared in the Journal of the Royal Geographical Society in March and October, 1910, and February and October, 1911. For the first eight months the party worked together in the upper Yenisei regions and in Mongolia. During the concluding eleven months Mr. Miller and I travelled in Dzungaria, and then crossed Turkestan to India, arriving home in December, 1911; whilst Mr. Price journeyed through Russian-Turkestan and the Caucasus, and reached England in March, 1911. My thanks, and the thanks of all geographers, are due to the above-mentioned gentlemen-Mr. J. H. Miller and Mr. M. P. Pricewho bore the entire expenses of this journey, and on whose never-failing energy and keenness the success of the expedition largely depended.

$$
\text { No. VI.-June, 1912.] }
$$


Altai, and thence to Zaizan. Of course, I do not enumerate those who have merely traversed the Chinese Imperial High-road, and have left no account of Dzungaria proper. But amongst the Russian explorers, we have the illustrious names of Prjevalsky, Kozloff, Potanin, Piertzov, Matoussowski, and others. The Russian does everything on a vast scale, his journeys are colossal undertakings. Prjevalsky, the pioneer, covered 19,500 miles of route and spent nine years and four months over it. Kozloff has crossed the Great Gobi five times and in three different directions.

To these great travellers we are indebted for all our knowledge of that immense aren which stretches from Siberia to the Great Wall of China. The accounts of these journeys fill numerous bulky volumes but, alas! their contents are hidden from most of us. For this reason $I$ am trying to put on record all the information that I can possibly collect about the region, so as to give a fair idea of the vast stretches of country which are, to all intents and purposes, an unknown land to the English reader.

The subject of Mongolia has always had a hazy mystery attached to it, and has always been one of absorbing interest. There lies the ancient home of the greatest Asiatic races--the Mongol and the Turk, whose descendants now rule in Pekin and Stamboul. There rose the Uigur civilization, whose origin is shrouded in immense antiquity; those are the wind-swept plateaus which gave birth to the Mongol demi-god, Jenghis-Khan.

Of late years Mongolia has attracted but little attention in the West. It was in the twelfth century that Europe was really interested in Mongolia. She was then staggered by the reports that reached her of the triumphs of that semi-mythical personage "Prester John" Khan of the Keraits. Embassies went to and fro. High Asia loomed large in the imagination of the peoples of Europe in the twelfth century. Then came the Mongol invasion, and the Wesiern world learnt only too well to appreciate the demon-like ferocity and barbarity of the Tartars.

But since the destruction of the Mongol power, Tartary has sunk into oblivion. The centre of interest has shifted to Cathay. Formerly the Tartars were only approached by the landward gates. Embassies and missions braved the 3000 miles of Asiatic steppe, in order to reach the courts of the Khans of Karakorum. But, later, the depths of Mongolia were forgotten, for men sailed in ships to the great ports of China. Europe keeps but one impression of Mongolia-that of a far, bleak land, where the remnant of a great people wander in semi-barbarism, of black-felt tents and countless flocks, and of a restless spirit, which might again one day " burst all link of habit" and overrun the West.

Although scope for pioneer work is about as hard to find here as it is now in Africa, or, for that mattor, anywhere else in the world, yet a great deal of detailed geographical work remains to be done. By the careful study of the labours of all previous travellers in these regions, we have 
been able to spend nearly two years in traversing large areas of littleknown country, adding to our stock of knowledge of the fauna and flora, and making considerable addition to the existing maps.

The region which we chose as a field of work comprised: (1) The northern declivities of the Mongolian platean, to the west of Lake Baikal. Here the headwaters of the Yenisei river, which rise in a mountain-girt basin on the plateau, break through the enclosing ring of mountains and debouch on to the Siberian lowlands. The topography of the whole of this basin is but vaguely sketched on the existing maps. It possesses an interesting population and curious conditions-half Mongol, half Siberian. (2) North-western Mongolia, in the region of the lakes called Ubsa, Uriur, and Achit Nor, together with the glacial range of Turgun or Kundelun. (3) The extreme eastern end of Tian Shan mountains, namely, the Karlik 'Tagh and Bar-Kul ranges. Here our work consisted of a thorough revision of the maps and an investigation into the fauna of the region.

Besides this, we traversed the whole of the intervening region of Dzungaria, chiefly with the object of forming natural history collections. But the nine months we spent on its inhospitable deserts and border mountain ranges will enable us to put on record much of interest as regards the people, topography, zoology, and the present conditions of a land which may some day be of account.

It is barely possible here to touch on any but the leading features of the country traversed. Detailed accounts of each subject will be dealt with separately, I hope, at some future date.

Our party made a start early in June from the Siberian frontier village of Kuzhabar, which is situated on the edge of the forest zone, within view of the Syansk mountains which lie to the south. All the way from the Siberian railway, which we left at Atchinsk, we had traversed the good, black-soil area, with its well-to-do population of colonists. Minnusinsk was the last of the Russian towns and Kuzhabar the last village we saw. After leaving Kuzhabar, for four and a half months of travel and for about 1000 miles traversed between there and Chuguchak on the borders of Semipalatinsk and Dzungaria, we touched on but one small settlement of Tartars and Uriankhai, and one of Chinese and Chantos. This entire region is a Nomad's land.

Up to the edge of the forest reach the settlements of Siberian colonists, mixed with a few Avakan Tartars and still fewer Kalmuks. Here, where the rich, open plain lands of Siberia end and the country rises towards the first steps of the Mongolian plateau, terminates the advance of Russian colonization. Beyond lies the unknown depths of forest, backed by the border ranges that serve as a frontier to the Chinese Empire.

Leaving Kuzhabar on June 2, 1910, we spent the next two and a half months amongst"the forests, on the lakes and waterways at the sources of the upper Yenisei. 
The basin of the upper Yenisei comprises the area drained by the rivers called the Kemchik and the Ulu.Kem, whose two heads are the Khua-Kem and Bei-Kem. The area is roughly 64,000 square miles. These two rivers, the Kemchik and Ulu-Kem unite, before bursting through the mountain wall of the Syansk range, at the point called the Kemchik Bom. The encircling wall of ranges round the basin is complete, except at this point, where a deep-cut ravine lets the drainage out through a series of rapids on to the Siberian lowlands. From the neighbourhood of Minnusink to the Arctic ocean the Yenisei has a drop of only 900 feet. Its height at Cha-Kul, in the basin, is 1656 feet.

The average height of the floor of the basin might be taken at between 2000 and 3000 feet, whilst the border ranges rise to between 8000 and 9000 feet in places, but have numerous passes and cols of 4000 to 5000 feet altitude.

After a most arduous trek of eleven days through dense forest we emerged on to the Syansk range. During these days we had plunged almost blindly through the tangled undergrowth and bogs of virgin forests. We made about 5 miles a day. Men, in advance, cleared the way with axes for the baggage-horses, which were sorely tried by the fallen timber, the heary going, and the myriads of mosquitoes. We seldom got any view. Damp, sodden forest walled us in, fostoons of lichen hung from the branches, showing hoary white against the dark pines. Trunks piled on trunks lay across the ground, all clothed in moss. Swampy bottoms, half lake, half forest, looked so mysterious, that if some prehistoric monster had raised its snaky head to have a look at us, it wonld not have been surprising. We should have felt its presence was all in keeping with its surroundings, and was, in fact, more natural than our own.

We appreciated the change by comparison when at length we toiled to a summit of the Syansk and gazed down for the first time into the secluded basin beyond. The forest had led us up to beautiful upland meadow, knee-deep in marigolds and luxuriant bog-plants. Higher we climbed over moss, lichen, and dwarf rhododendron to rocky screes and a snow-patched summit. Beyond and below were long reaches of pleasanter country, park-like meadows, and depth of forest; winding rivers show here and there, and rocky summits of distant ranges rose above the "taiga."

The Syansk range, which together with the Tannu-ola mountains encloses the basin, is of no great altitude, but its appearance is enhanced by the peculiarly rough jagged summits, which it lifts up above the forests. We found these summits to be very variable in character ; some were of wind-worn granite and of excessive steepness, others were rounded and worn smooth, and very easy of access. The highest summit we attained was only 8200 feet, and it is doubtful if they rise above 9000 feet in any place. Broadly speaking, the Syansk range forms the first step from the Siberian lowlands to the Mongolian plateau. The upper Yenisei 
basin beyond is the first terrace. The Tannu-ola, which borders the basin on the sonth, is the second step which leads up to the main plateau, viz. Mongolia proper. The first terrace possesses none of the features peculiar to Mongolia. It belongs to Siberia rather than the dry plateau land to the south. The dense forests of Scotch pine, larch, and spruce show this. The inhabitants are not pure Mongol, but a forest-dwelling race of Finno-Tartar stock, very different to the nomads of the wide, open steppes of Mongolia. But still, even in the basin, the transition stage between Mongolia and Siberia can be noticed. The northern and eastern parts are almost entirely covered with forests; lower down, in the central portion, open expanses of grass-lands appear, and little bits of steppe along the river-banks. In the south and south-west this increases, whilst the forests occupy less space. The Tannu-ola is the true dividing line, for on reaching its summit all forests stop, and we enter the drier, treeless plateau region.

We made many ascents on to the different isolated uplifts which form, as a whole, the Syansk range- "Taiga," as they are called by the superstitious dwellers in the forests below. For those naked summits of rock which lift themselves above the silent forest have a peculiarly uncanny atmosphere. The Uriankhai deem them haunted, and call them "Taiga," i.e. "The Wild." Fallen timber, dense tangle of rhododendron, and soft bogs made the lower slopes difficult to negotiate, whilst the summits were in most cases composed of gigantic screes of huge granite boulders. In some instances these were flat-topped, and in others capped by a serrated ridge of wall-like steepness. Want of symmetry in the uplifts, a difference in the structure and texture of the rocks, caused a watershed of no uniformity. As an unbroken range the Syansk does not exist. The watershed forms great zigzags, and the upper waters of the rivers flowing north and south are dovetailed in between each other.

Mapping in this region was fascinating work, but tedious and overpowering by the very magnitude of it. Here were thousands of square miles of absolutely unmapped country laid out around one. The difficulty of even roughly surveying was inconceivable. Looking down into a valley, it was impossible to tell if it drained into China or Siberia. A group of lakes in a marshy flat might drain into different river systems. One climbed tediously through dense forest on to a ridge, only to find all view obstructed by timber, and one had to search diligently amongst a maze of bogs and lakelets for the water-partings. The scenery is one of extreme opposites. Nothing could be more monotonous than the endless expanse of unbroken, sombre forest, and nothing more striking than the upheavals of bare, jagged peaks that rise suddenly out of it. Orerlooking the central basin, one is almost repulsed by the dreary monotony of the landscape, the ridge after ridge of endless sodden forest, and the uninspiring reaches of "taiga." Only do the eyes find repose and satisfaction when the contrast is given, and they rest on some jagged mass of 
snow-patched rock and crag, heaved up out of the forest far into the sky, whose altitude defies the forest and where naked rock holds sway.

Although the greater portion of the country is forested, yet certain parts are composed of idyllic park courtry of " rolling grass and open timber" dotted with lakes, and supporting a considerable population of nomadic Uriankhai. We had expected to find the region at the sources of the Yeniaei idyllic, and we were not disappointed. Here was a land of sunny meadows and shadowy forest, dancing streamlets and great swirling rivers. Here the Nature-worshipping Uriankhai dwelt in picturesque encampments. Here was a lakeland of a thousand lakelets, where great fish rose and the "loon" laughed. Yet always at the back we had a glimpse of the border ranges, which gave one the impression of being hemmed in, of being in a secluded valley, shut off from the outer world.

Were it not for the waterways, travel would be exceedingly difficult. We often used canoes for river journeys, and actually transported the whole expedition, kit and all, down the Bei-Kem and Ula-Kem for 180 miles by raft.

The excellent fish that swim in these rivers attract many Siberians in the summer months. These men come up by canoe, fish all the summer, pack and salt their catch in barrels, and finally raft it down the Yenisei to the big Siberian towns, Minnusinsk and Krasnoyarsk. Fur-hunters, too, penetrate into the recesses of the forest in search of the sable, for which this region is famed. Apart from these there are but few colonists, for this region is virtually under the suzerainty of China.

In such a secluded region a peculiar inhabitant might be guessed at. The Uriankhai, the only indigenous inhabitants of the basin, are a race of Finno-Tartar stock; that is to say, of a race possessing the characters of both the Mongol and the Finn. There is not very much known about these tribes. They are doubtless the original Uriankhai, or Uriankut, one of the six divisions of the Mongol people early in the sixteenth century, but the word merely signifies "forest-dweller," and we find mention, also, of Uriankhai in Siberia and on Lake Kossogol.

Sir Henry Howorth thinks that the present Uriankhai of the upper Yenisei basin are the descendants of the ancient inhabitants called, generically, Yeniseians. These people have left traces of their old distribution all over the Avakan and Chulym steppes, in the shape of great burial-mounds, stone circles, and rock-cut inscriptions-in a langaage still undecipherable. Stone, bronze, and iron instruments have been found in the mounds. From the original Yeniseians sprang the Samoyedes, who were driven, by the incoming hordes of Kirghiz (Kazak ?), into the treeless north country within the Arctic circle; whilst their kinsmen, the Uriankhai, who are the forest-dwellers to this day, were pushed back into the secluded valleys of the upper Yenisei basin. The fact that these people still call themselves "Tuba" is of importance, and they certainly ranged northwards as far as the river of that name until a comparatively 


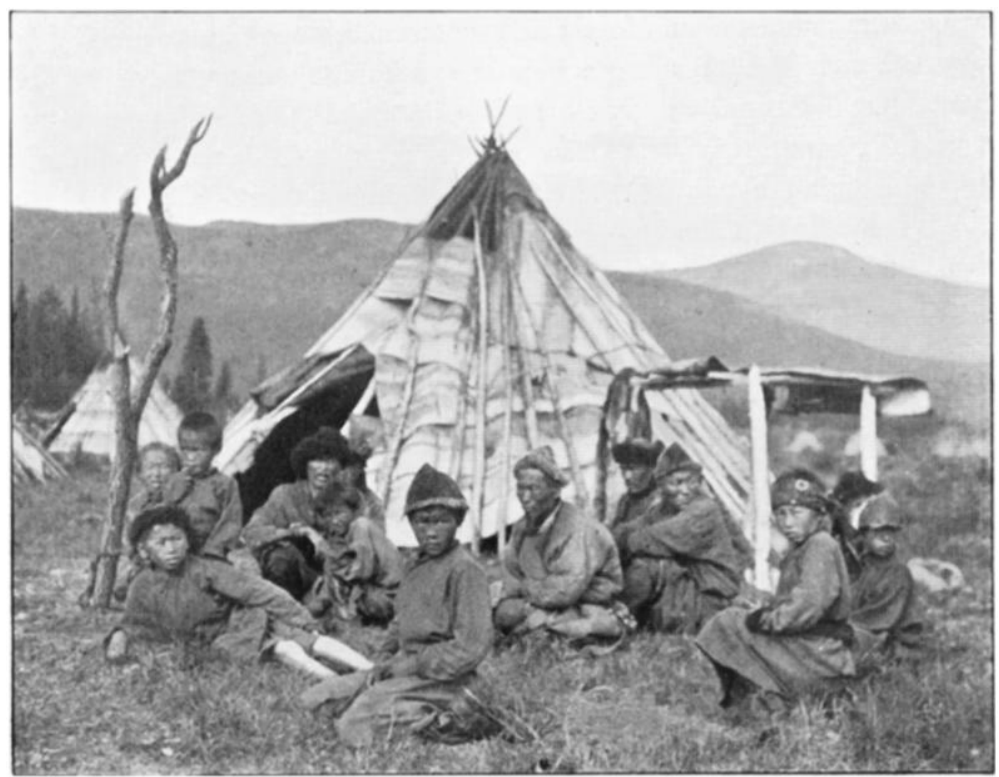

URIANKHAI FAMILY GROUP AND "TEPEE" IN THE UPPER YENISEI BASIN.

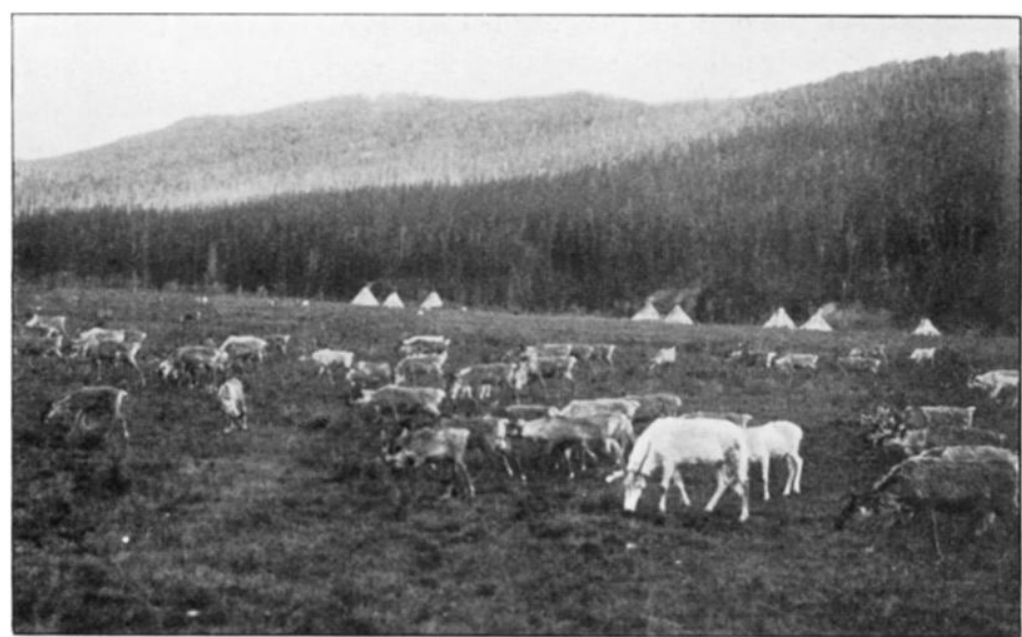

TYPICAL ENCAMPMENT OF URIANKHAI. HERDS OF REINDEER IN FOREGROUND. 


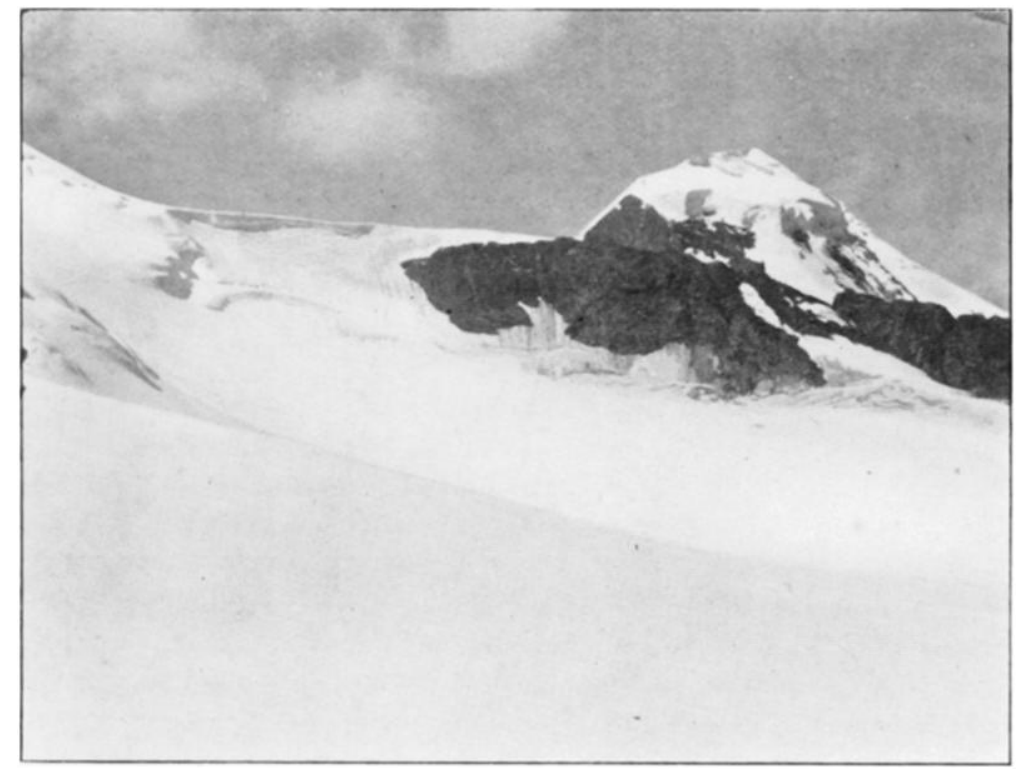

"KUNDELEN" OR "KHARKIR" PEAK, IN THE TURGUN GROUP.

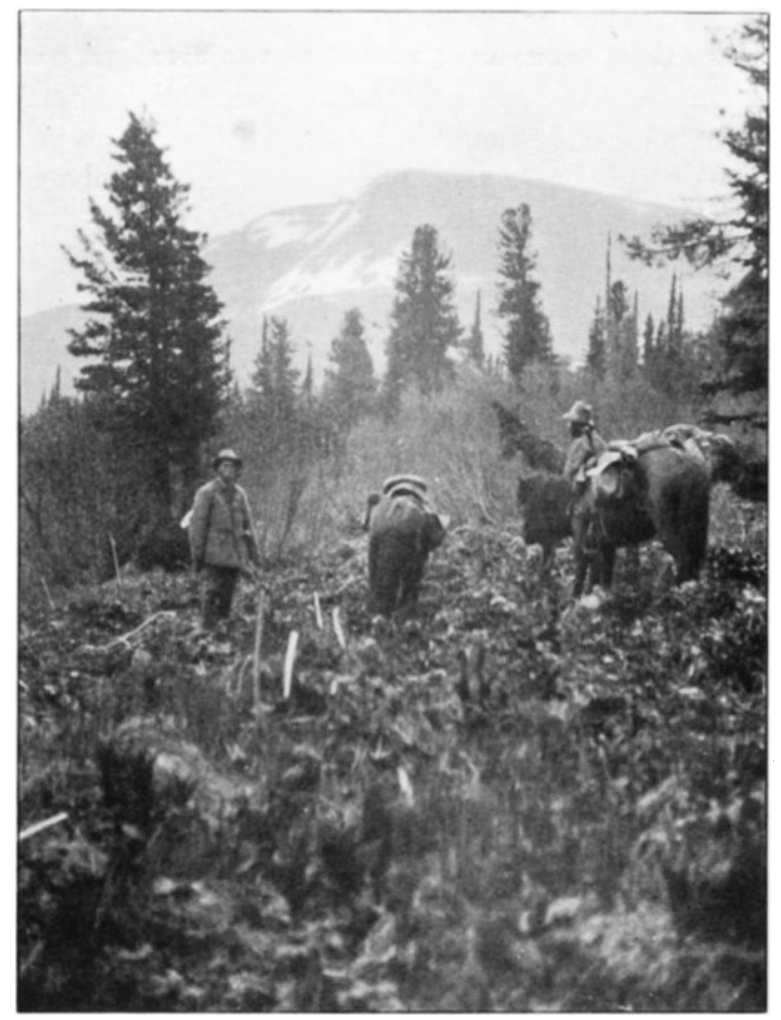

TYPICAL SCENERY IN THE SYANSK MOUNTAINS. ALTITUDE 6000 FEET. 
recent date. At the present day, their isolated habitat protects and preserves them from the forward march of more powerful tribes.

These peculiar people, shy, superstitious, and unconth, live in isolated encampments all over the basin, and apparently do not extend beyond the border ranges. Their southern limit is marked by the line of Mongol "karauls," or guard-houses, which are to be found dotted, at intervals of about thirty versts apart, all along the southern foothills of the Tannuola range. They are divided into five tribes, of which only two are true forest-dwellers, dwelling in birch-bark tepees, and dependent upon their herds of reindeer for existence. This latter peculiarity is of interest in that this is the most southerly range of the reindeer. Their locality here, moreover, is isolated; their nearest neighbours are those belonging to the Tunguses of the Vitim plateau, to the east of Lake Baikal. It seems almost as if the Uriankhai and their reindeer have been left "stranded," as it were, in this isolated highland. Ages ago, when the ice-belt shifted northwards, these tribes were left on this insular mountain-top, which still preserves something of the nature of what the lowlands possessed in those days. It is a case of altitude compensating for latitude.

On different occasions we visited the various tribes of the Uriankhai in many different localities, and got a very good idea of the peculiar conditions under which they live. But as the geographical material of this journey is in itself more than we can deal with in this paper, I shall leave these more ethnological subjects to be described at length elsowhere. Briefly, the Uriankhai * are semi-nomadic people who inhabit, sparsely, the whole of the upper Yenisei regions. In the forest areas they utilize birchbark " tepees" or "wigwams," but on the open grass-lands of the Ulukem and Kemchik the ordinary felt-covered yurt, as in general use by all nomads from Manchuria to Asia Minor.

We speak of them as being nomadic, but this is only as condition makes. Many encampments make only two moves in the year, and then only for a very short distance-a summer and a winter residence, in fact. But the reindeer-keeping tribes probably shift camp more often. Their spring and autumn migrations are movements of some consequence, since their reindeer need the cool heights of the "Taiga" during the summer's heat. At this season their white "tepees" cluster in some high meadow valley, where pasture is so abundant as to last all through the hot months. Here on marigold-strewn boglands feed the herds of reindeer, wandering at will, but spending the heat of the day panting under the shade of the spruce forests. It seemed, almost, as if this southern clime was getting too hot for them. As to the natural history of the reindeer, both wild and

* The Uriankhai generally appear in Russian literature as Soiots. This is probably due to the fact that there is a tribe of reindeer-keepers in Central Siberia called Soiot, and the first explorers of these regions recognizing the likeness in habits of the Uriankhai, called them by the same name. The natives call themselves "Tubas." 
domesticated, my companion, Mr. J. H. Miller, made copious notes and collected much detailed information, which he will publish elsewhere.

A few of the traits of these curious people may prove of interest, from the point of view that environment is the strongest factor in determining character. We have shown how superstitious they are, which is accounted for by innate fear of all things they cannot understand. Their shyness, dislike of strangers, and dread of their lamas and chiefs are again the result of superstition and seclusion. Sadness and melancholia are stamped on their faces, as is natural to a people who are in constant fear of the "genii" of the mountains, rivers, and forests, whose whole time is taken up with propitiating the gods lest evil befall them. The Uriankhai is a product of the forest as the Arab is of the desert. The one is the antithesis of the other. Environment has moulded the character of each to his surroundings. The fearless believer in one God, the nomad of the sunlit desert, compares strikingly with the superstitious inhabitants of dark, damp forests, fearsome of evil spirits, and cringing under their witch-doctors. All through life the forest-dweller is in fear of offending the deities, and at death his corpse is carried out and placed on some lone hilltop, where the wild beasts are expected to devour it if the man has led a good life; but bad Uriankhai have not that doubtful honour bestowed upon them.

There seems to be a certain limitation to the ideas of the Uriankhai. Although he lives in a land of rivers and is in constant need of rivertransport, yet he possesses no craft. He makes all his household utensils of birch bark or reindeer skin, but has never learnt to make a canoe. It is true he resorts to a raft when forced, by necessity, to transport goods down-stream or in order to fish on the lakes, and under Russian teaching they become good boatmen, but he has failed to make use of the great waterways that intersect his native country. Fish swarm in extraordinary numbers in the rivers and lakes of the basin, but we found that the native only catches them, in a desultory manner, in the backwaters, using a primitive net of horsehair. $\mathrm{He}$ is lazy and independent to a degree. He works when he has a desire to work, but he would far sooner run wild in the forests, hunting the roe, elk, and wapiti, and live in comparative poverty, than work for the Siberian colonists and thereby earn a good wage. $\mathrm{He}$ has no desire to better himself. Herdsmen and hunters by profession, living entirely on the produce of their flocks of reindeer, they live a life of contentment, even if of considerable hardship. Their skill in hunting equals that of the North American Indians. The fact that this region is a very fine fur country makes the Uriankhai of some value to fur traders, and gives him in return an ample supply of the necessities of life. The Siberian traders advance him tea, tobacco, etc., and he probably pays off his yearly account in furs and skins by a month's hunting.

Amongst a people living in densely forested regions, isolated in remote secladed valleys, shut off from the outside world and surrounded only by and dependent solely upon Nature, superstition, of course, runs riot. His 
superstition takes outward form in that crudest and most primitive of all religions-Shamanism or Nature worship. It consists primarily of the propitiation of evil spirits, resulting, of course, from fear-fear being the original foundation of all religion. Shamanism is rather a system of propitiation than the worship of a deity. The mystery of the sodden, "taiga"-clothed hills, the dark silent valleys, and the mountain crags that toss their height above the forest, fill him with awe and crowd his thoughts with superstition. The Uriankhai, in their simple faith, see mystery, and therefore the supernatural on all sides, and hasten to appease the gods for fear of offending. The howling wind is obviously a god in anger; the swift-running river gods hinder his crossing and jeopardize his life; the lonely summits of granite boulders, storm-riven and streaked with snow, are surely the thrones of gods and not fit places for men. The abundance of sudden storms, thunder and lightning add to his nervousness. The "terror of Pan" is everywhere. A crude race, which is dependent solely upon Nature for all its wants, naturally worships the hand that gives. Shamanism is rife, and nature-worship is practised under a thin guise of Buddhism. On every possible occasion the Uriankhai propitiate the gods in order to avoid harm at their hands. Buddhist lamas have some power amongst them, but in the case of sickness, at any rate, the Uriankbai invariably resort to Shamanism. Demons of sickness require the practised hand of the witch-doctor. When it is the shadow of death that falls on them, then, with "tired" head, beating drums, and drooning chant, the Shaman doctor wearies bimself out in delirious madness.

The Buddhist element is noticed especially at the centres of Uriankhai life, such as the Dora-Kem steppes in the upper portion of the basin and at the Chedan valley in the Kemchik. At both of these places a considerable population was concentrated; these were the headquarters of chiefs, and each possessed a Buddhist place of worship, designated "kurin." Many such exist, but we saw only these two.

It would be quite impossible to give an estimate of the population of the upper Yenisei basin. M. Paul Chalon;gives the maximum population at about 100,000 souls, and the area of the Uriankhai territory at 120,000 square versts, or 52,555 square miles. It suffices to say that there are vast areas of splendid country untenanted, which means a very sparso population in proportion to the area. Now and again one finds a valley with a considerable population (these are always the drier valleys, occupied by yurt-dwellers, the wigwam or "tepees" dwellers generally being found in small isolated encampments), but on the other hand, one travels for days without seeing a native. The land could support a much larger population. Excellent pasture-lands, untouched fisheries, and mineral wealth lie awaiting the future colonist.

The fauna of the basin and its surrounding ranges includes some curious types. Besides being the most southern limit of the reindeer in a wild and domestic state, the rivers constitute the home of a few beavers. 
Elk, wapiti, roedeer, muskdeer, and bears haunt the forests and form the quarry of the Uriankhai hunters. The furs are of excellent quality. In the old days the tribute of the Mongol Khans consisted largely of furs; as part of a tribute sent to the Czar of Russia by the Khan of the Ubsa region, we read of "a hundred sables and two beavers."

After penetrating to the little-known country that lies at the north-east corner of the basin, midway between the Yenisei waters and Lake Baikal, where every physical feature which we mapped-lakes, ranges, and rivers - were new to existing surveys, our party divided. Messre. Miller and Price visited the lake-land of the upper Bei-Kem, saw that mysterious Toji-Kul, lake of crystalline beauty, and centre of Uriankhai life in the upper basin. Meanwhile, I made further maps in the central portion between the Bei-Kem and Khua-Kem. Then the whole party drifted down the river by raft to $\mathrm{Cha}-\mathrm{Kul}$, on the Ulu-Kem, the trading centre of the basin. Here a nondescript collection of Tartars, Uriankhai, a few Russians, and even a Chinese or two live by trading with the natives.

So far our survey work had been of extreme difficulty. Dense forests made prismatic-compass work alone possible. But at slow pace we carefully filled in large areas, and by collecting and making use of all previous knowledge we hope to give a fair idea of the whole topography of the basin. From Cha-Kul onwards the open nature of the country made work easier. We found ample scope in the country to the south of Kemchik, on our way over the Tannu-ola, every feature being new to existing maps. The variety of scenery, viz. dense forest and open steppe, is such a factor in determining the distribution of the inhabitants, etc., that we have shown this on our maps as clearly as possible.

The only routes that cross the basin, keep, of course, to the open country. There is an ancient route that leads between Uliassutai in North Mongolia to the Avakan steppes of the Yenisei. It crosses the Tannu-ola by the Chamar Daba, passes along the south side of the basin, across the Kemchik and over the western Syansk range. This can be used for wheeled traffic. A portion of it between Cha-Kul and the Kemchik at Bievkoff presents the appearance of a Roman highway. It runs perfectly straight, is raised above the level of the surrounding steppe, has a wellmetalled surface, and a drainage ditch on either side. Natives say it was made a thousand years ago; it was probably the work of some Mongol khan. There is little to deduce from it. In fact, it seems to be a " folly," made with no object. The country this route passes over is the sort that does not need road-building. It is open, dry steppe over which one could drive in any direction, whereas if it had been in the forest and bog area, one could well imagine what a boon it would be to travellers and for transport. At any rate, it shows that once this Cha-Kul steppe was an important locality, and the territory of some powerful prince.

In the drier parts of the basin, where steppe conditions are making themselves felt, we find the Uriankhai living the quaint life of a semi-sedentary 
character. Still living in the easily-shifted yurts, they cultivate patches of land where they grow millet, barley, and wheat. There are also traces of a much larger area of land being under cultivation in old days. These facts bring up the question of who were the ancient inhabitants, traces of whose handiwork so often showed themselves. Evidently they were a more important and more advanced people than the degenerate tribes of the present day. No mere tent-dwellers scattered the land with stone monuments, carred pillars, and irrigation canals. Those ancient people had more ambition than the herding of reindeer and cattle. Our first introduction to these old sites was on the road between Atchinsk, on the Siberian railway, and Minnusinsk. Here, where we first encountered the pasture lands, namely, the steppes on the banks of the Chulym river, there we first found "kurgans," or "tumuli"-grave mounds - surrounded by circles of upright stone slabs. All along the Avakan steppes they were extremely numerous. Later, in the Cha-Kul steppe of the Kemchik valley, we found a few relics, bat as we journeyed southwards they became less numerous. Beyond the Altai in Dzungaria, the only remains were grave mounds. It appears as if the main habitat of these ancient people-the Yeniseians, and later the Uigurs-extended over the whole of north-west Mongolia, the Yenisei basin, and the Avakan steppe ou the edge of the Siberian plains. According to M. Grano, of Helsingfors, the majority of the inscriptions are old Turkish, hence the deduction that it formed a part of the Uigurs' empire-that ancicnt nation which existed long ago, and about which the most learned historians know scarcely anything. In many parts of the Yenisei basin there are evidences to show that these people had a much larger area of land under cultivation than there is at the present day. Old irrigation canals are so numerous in the Uik (Ujuk) valley, that the Russian colonists have opened them up afresh and used them with success. These cultivated areas are the localities of the greatest number of graves and carved pillars, etc. Antiquities of this kind extend to the southwards over the basins of Ubsa Nor, Atchit Nor, and Uriur Nor, towards Kobdo and Uliassutai, and as far as the ancient Karakorum. All these inscriptions are apparently old Turkish.

But there are also traces of an older race than the Uigurs, extending all over the northern part of this region. The complete collections dug up near Minnusinsk and preserved in the museum there, give a wonderful representation of art in the Bronze and Iron ages. Skulls of pre-historic man have been found in some of the grave mounds. It is said that these inhabitants of the Minnusinsk region, who, by the way, were skilled workers in metals and good agriculturists, were the origin of the Samoyedes and Uriankhai. There is evidence to show that the whole of the black-soil region of southern Siberia was occupied by pre-historic man.

After spending some time amongst the Uriankhai of the Chedan valley, and mapping the river of that name up to its source under the crests of the Tannu-ola, we passed out of the basin, over the watershed, 
into Mongolia proper. 'The contrast was surprising, the Tannu-ola being the actual watershed between Arctic drainage and the inland self-contained basins of northern Mongolia. From the summits of this range we gazed back into dark, stormy Siberia, where forests covered the majority of the landscape. Before us lay the pale steppes of Inner Asia, giving an impression of light, aridity, and unrest. The Tannu-ola, like the Syansk, was a range of no great altitude. We crossed it by the Borashay pass at a height of 6854 feet. Summits, all of them peculiarly flat topped, rose to 7500 feet on either hand. Forests climbed up their northern sides, but the southern slopes were barren. Here, in fact, we reached the true Mongolian plateau.

Passing to the south-west in the month of August, we sighted a high glaciated mountain mass, which attracted our attention on account of the remarkable beauty of its summits and the great amount of snow and ice that covered them. The maps of this region being very poor in detail, we carefully surveyed the western declivities of the range, and filled in the features between there and Achit-Nor. The Turgun or Kundelun range is the headquarters of the Durbet Dalai Khan, one of the many hereditary ruling Mongol chiefs, and his tribe.* In this very beautiful platean land we found the Mongols living in great numbers, apparently well-to-do and with ample good land at their disposal. The main valley, the Kundilun, was the summer headquarters of the tribe. Here in a well-watered meadow were the yurts of the Dalai Khan (or great chief), and close by was a religious settlement, with its kurins, temples, lamaseries, and a few houses belonging to Chinese traders.

During our journey, again and again there came up the question of the decrease, deterioration, and fall of the once-powerful Mongols. There seems to be no cause for this decadence but religion. We may almost say that had the Mongols embraced Islam they would have risen in the scale rather than have lowered themselves. Islam is known to be an equalizing force. Buddhism, on the other hand, invariably places the people under the absolute power of the lamas. The one conduces to equality and democracy, whilst the other tends to create a lack of individuality and a return to servitude. Perhaps it was this knowledge that kept the Kalmuk chiefs from embracing Islam, for they realized it would be the end of their power. Huc, in his 'Travels in Tartary,' hints that the Chinese patronize Lamaism, endow the monasteries, and grant privileges to the lamas with the knowledge that so long as they have influence over the sacerdotal class, neither the people nor their chief will give any trouble. Their religion, as it is, debases them. Lamaism tends to decrease the population, to weaken the family ties, and to lessen the chances of

* There does not appear to be any definite name for this group of mountains, as a whole. Potanin gives Turgun for the northern summits and Kharkir for the southern. Kundelun or Kundelen is the name of a principal valley, which is the summer residence of the Dalai Khan, and owns a large lamaserie, called Kunde-kurin. 


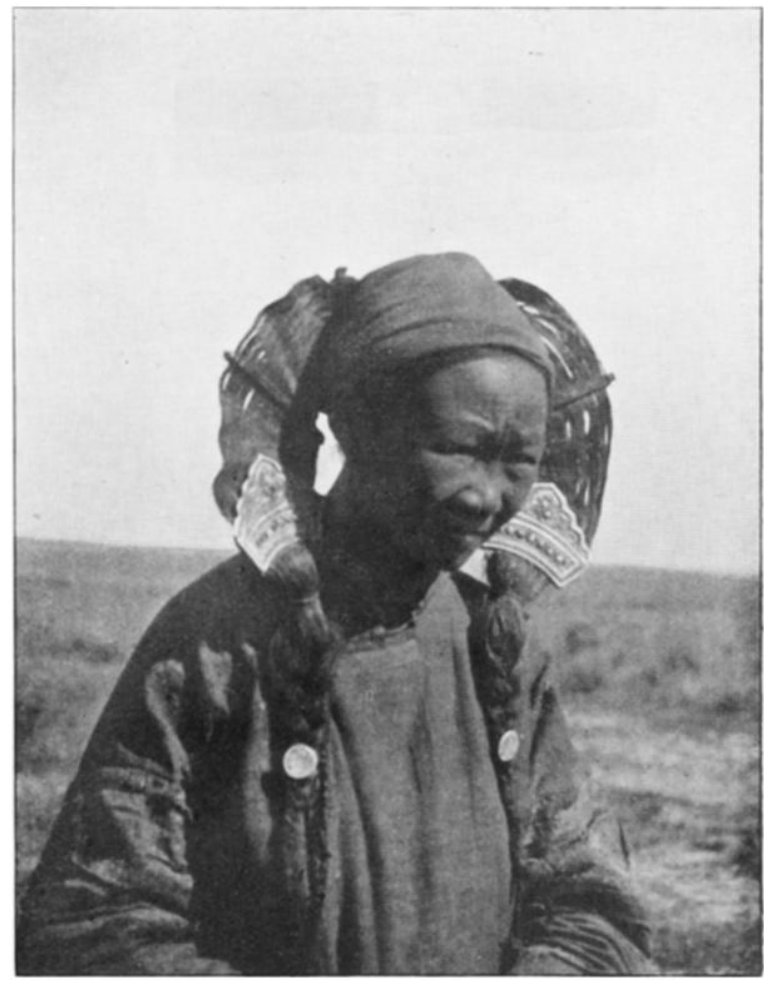

WOMAN OF THE KHALKA TRIBE.

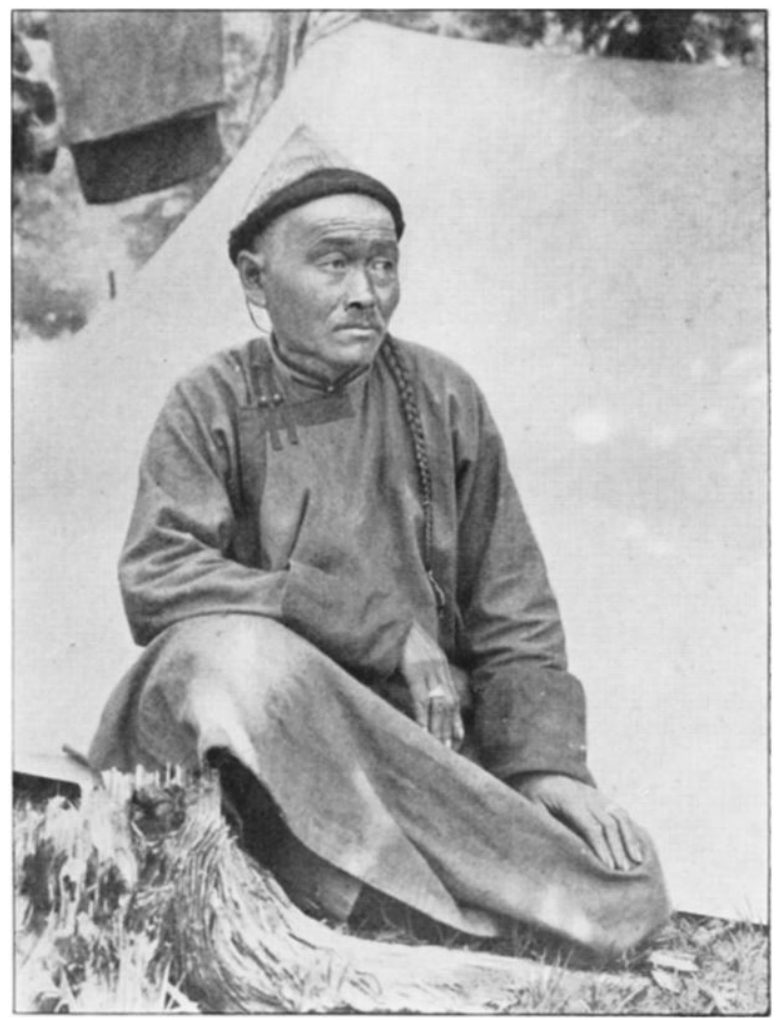

URIANKHAI TYPE.

This content downloaded from 142.51.1.212 on Thu, 05 May 2016 02:24:52 UTC All use subject to http://about.jstor.org/terms 

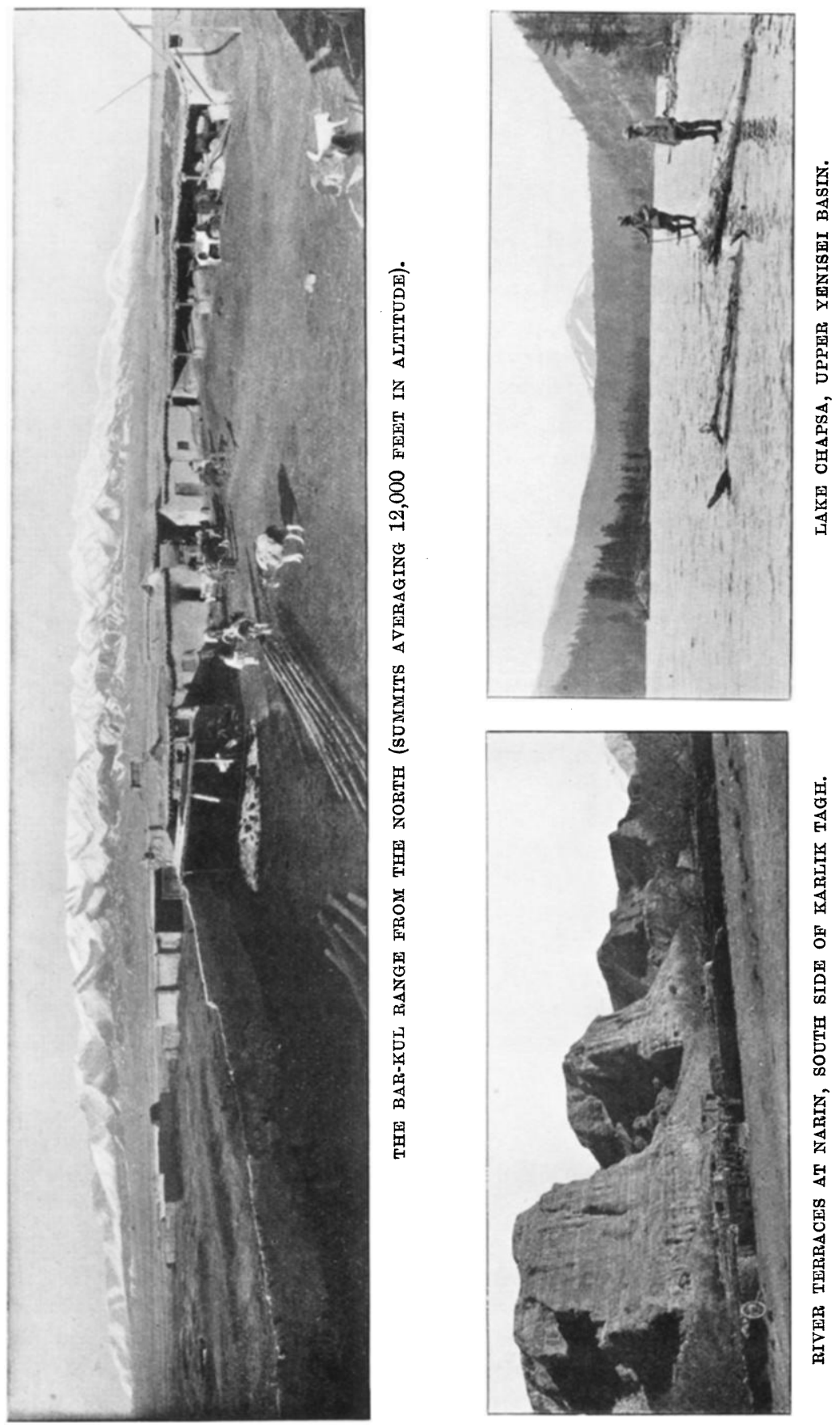

This content downloaded from 142.51.1.212 on Thu, 05 May 2016 02:24:52 UTC All use subject to http://about.jstor.org/terms 
economy and the increase of their herds. It also promotes immorality; hence disease, small families, and a weak type. But we liked the Mongol, from what we saw of him. Rough but very good-natured, timid and credulous as a child, yet a man amongst men when the dangers and hardships of the steppe are to be faced. He is the antithesis of the lethargic Turki races of Chinese Turkestan. Sturdy men, some of these Mongol cavaliers; one can well understand the terror that their hosts once struck into European hearts. Short but thickset, with most determined faces, and of an untiring energy when necessity forces action, but at other times unaccountably lazy.

It would be easy here to diverge into the realms of romance, and to theorize as to the cause of the great Mongol movements which terrorized the world early in the twelfth century. We could scarcely travel through this, their original home, wander amongst their black encampments, and ride all day with these children of Jenghis, without wondering as to what subtle force it was that drove them with such irresisible fury out towards the east. In these days of careful search, it is highly desirable that some scientific reason should be set forth for such world-wide movements as these. But it seems to be outside the scope of the present paper. There is too much to record, and it embraces so many different topics that I fear to embark on a subject which, besides not being in itself strictly geographical, is also not quite in keeping with this broad survey of the whole region.*

By the Mongol khans we were treated with the greatest respect and hospitality. Many an impressive and instructive interview had we with these chiefs, whose way of living and view of life must be very like those of the barons of England in the early ages. The chiefs possessed that inexpressible look of breed which marked a great social gap between them and their serfs. They gave us relays of horses and men to transport us from place to place; we were handed on from one local chief to another right across Mongolia, free of charge. Not that they wanted money, for they had no use for it, but chunks of brick tea delighted the hearts of those hardy nomads.

Our survey of the Turgun ranges was carried on by plane-table and prismatic compass. The remarkable beauty of this almost isolated highland, its Alpine valleys, forests of pine and larch, and high pastures, tenanted by the herds of yaks, leading up to glaciers and snowfields, attracted us more than anything else we saw in Mongolia. From its heights we gazed out over limitless expanse, across the basin of Ubsa Nor, a shining sea of turquoise in an ochreous steppe; across Urior Nor to the north-north-west, and over Achit Nor, which drains to the Kobdo river and finally to its, home of evaporation, the depression of Kirghiz Nor.

* I hope at some future date to be able to lay before the Research Department the results of my researches into the cause of the great Mongol migrations. 
Three separate self-contained basins at a glance! Although we speak of the glaciation and heavy snowfall on the Turgun mountains, it must not be supposed that the summits are of any remarkable altitude. We ascertained their heights by hypsometer and clinometer, and found none to reach above 13,350 feet. The glaciers extended down to 9550 feet, and in all cases they were in a state of retreat. Old moraines were to be seen one mile below the present snouts of the glaciers. The comparatively heavy precipitation is accounted for by the position of the range on the edge of a plateau overlnoking the low depression of Ubsa Nor. In midsummer we noticed that the range was constantly covered in clouds and mist-those great conservators of snow and ice. Consequently the heavy winter snowfall is preserved, and the glaciers, more or less, hold their own.* Wonderful pasturages cover the plateaus of the south-western part of the range, which were totally uninhabited, and, so far as we could ascertain, were never used. This is but one example of available land-untenanted. It cannot be said that the present state of the Mongols is due to lack of grazing country or climatic change.

The Turgun mountains supplied us with much of interest from the zoological point of view. Collections were kept up during the whole journey. In these mountains we first met with the Ovis ammon and the Altai snow-cock. Jolly little picas or tail-less hares (Ochotona pricei, sp. n.) swarmed in the rocky screes at an altitude of 8000 feet, and that magnificent polecat (Mustela eversmanni) was obtained on the Yamatu plateau. This region forms the northern limit of the yak, which we found in peculiarly isolated localities throughout our journey, namely, here, and in the Karlik Tagh, nearly 500 miles further south, until we came to its true habitat in Tibet.

Outer Mongolia is so vast and its different portions come under such varied climatic conditions that consequently its scenery is very contrastive. There are great delusions as to Mongolia. It is generally supposed to be arid and barren. Even Sir Francis Younghusband, who traversed it from east to west, along a line to the south of our route, never saw a tree in Mongolia, and was amazed at our descriptions of the forests to the north. Broadly speaking, Mongolia can be divided into four zones. The first or northern zone is that which comes under the influence of the Siberian climate. Here we have forests of larch and spruce, laxuriant meadows, and a great wealth of flowers, but on the other hand a comparatively scanty population-the ancient "wild Uriankhai," or forest dwellers. This zone stretches from the Altai along the north side of the Tannu-ola to the north of Uliassutai and Urga. South of this is the second zone, that of pastures. This is confined to the country below the forests and

* Potanin records the meteorology during twenty-three days between June 27 and July 19, on the east side of the Turgun mountains. Out of twenty-three days, seven were fine or clouded, and sixteen were wet. There were eleven thunderstorms, and twice it hailed. 
along the foothills. Further south still comes zone three, the true Gobi, which remains unatilized by man, except in the spring months. This desert zone occupies only one quarter of the whole of Mongolia. The Gobi stretches southwards until we come to Southern Mongolia, zone four. Here again Mongolia comes under the influence of the Pacific, and the result is a pastare land well named by the Chinese the "Land of high grass."

The region through which our route lay, between the Tannu-ola and Altai, was all plateau-land, averaging 5000 feet. Depressions and lakebeds drop 1500 feet. It is all good pasture land, and gets a considerable amount of summer rain. Ccnsequently the Mongols of the Durbet tribe abound, bat anywhere to the south of our route aridity begins to show itself, hills become drier, and the lowlands are desert. In the last week of August we descended to the basin of Achit-Nor, and Mr. Price visited the depression of Uriur Nor to the north. There he collected interesting data, which has a bearing upon the study of the ancient climate and inhabitants. Uriur Nor showed old strands up to 30 feet above the present water-level, and although it is surrounded by high mountains on the north and northwest, at a distance of from 5 to 10 miles, yet no streams reach the lake above ground. The water is fresh and full of fish, a fact which attracts great numbers of birds. The shores of Uriur Nor are scattered with " tumuli" and carved stones, showing that once the district was inhabited, whereas at the present day no nomads use that region.

On leaving the Achit Nor our geographical work came to an end. Although it was only the end of August, we experienced most severe weather. Snowstorms and blizzards struck us, making us hurry on, for the Great Altai still lay between us and the low plain of Dzungaria. The climate of this part of Mongolia, which averages about 5000 feet in height, and is intersected and surrounded by higher mountain ranges, is one of great severity. The summer is very short and hot, whilst the winter is correspondingly cold and long. During the first part of September our camp was under snow on several occasions. Passing through the plateau land of Uigur and by the beantiful island-studded Kobo lakes, we crossed the Altai by the Urkhogaitu pass at 9711 feet. On both slopes of the Altai we came across the first Mussulman tribes - the Kirei. These interesting people, who, as Nestorian Christians, drove out the Uigurs and established themselves on the north-east side of the Altai ranges, are best known as the Keraites, whose fame spread throughout Europe in the eleventh-twelfth century, as the tribe under the direct chieftainship of the Great Khan"Prester John." They still have a somewhat superior bearing, and are exceptionally fine men. The Kirei, the outpost of Islam in the north-east, are over 3000 miles from their Mecca, yet we found amongst them a few old men who had made the pilgrimage.

The next ten months were occupied in covering some 3000 miles in Dzungaria and its border ranges. First of all, we traversed the region 
between the Altai and Chuguchak to Kulja, in the Iii valley. Ronghly speaking, this route led along the frontiers of China and Russia: It took us across the valley of the Black Irtish and showed the Kirei in their winter quarters. This is the very place which Jenghis Khan made his rendezvous, and where he collected his troops before' starting on his conquests westwards. Further we passed again into a Mongol reservation, the Kobuk valley, and noted the awful deterioration that has beset the Kalmuks of the Torgut tribe living here. We found large encampments of these Kalmuks already settled in their winter quarters, around the group of buildings which comprises the residence of the khan and the monastery of the lamas. These are the remnant of the tribes which at the end of the seventeenth century made that great migration westwards to the Volga. Later the made a movement which has been compared to the Exodus of the Ishmaelites. The whole tribe attempted to return to their own land. After untold sufferings, being harassed by enemies and decimated by disease, they reached Chinese territory. Thə remnant now exists here in the Kobuk, on the Yulduz plateau, and in the Kash and Kunguz valleys of the Tian Shan.

Arriving in Kulja just before winter came on, we halted there for two months. Great cold, was experienced, the first snap during the last days of November registering a minimum of $22^{\circ} \mathrm{Fahr}$. At Kulja we sent off our collections, and our party was diminished by the loss of Mr. Price, who retarned through Russian Turkestan and the Caucasus to England.

In January Mr. Miller and I passed along the Chinese Imperial Highland as far as Hami and Bar-Kul, and, after working in these regions for two months, retraced our steps across Dzungaria, visiting en route the sacred mountain of Bogdo-ola in the south, and the Barlik, Ala-Tau, and Borotala regions in the north-west. At the end of July we arrived back at Kulja.

Dzungaria, situated as it is on the threshold of the Moslem and Buddhist worlds, in a region which has been the camping-ground for all the wild tribes which at different periods have overrun Asia, has been the prey of each successive wave of migration which has broken across these boundless steppes. It has been the home of wars and massacres on such a scale as only Asia can produce, and is in consequence a veritable "Land of Unrest." Dzungaria, i.e. the land of the "Zungars" or "lefthand Kalmuks," has been, in turn, invaded by the Huns and overrun by the Mongols. In the seventeenth century it was the seat of a great power-the Zungars, who suddenly rose to eminence, overran wide areas of Asia, then collapsed (like the rest), and of whom there is now nothing left but the name. In the eighteenth century (1756) the Chinese invaded it and killed off the population to a man; of six hundred thousand inhabitants not a Zungar remained. In order to repopulate the country they had devastated, the Dungans (Mohammedan Chinese) were transported 
from Western China to colonize Dzungaria. Later, in the last century (1864) it was again the scene of massacres, when Islam rose against Cathay, and the Dungans killed some hundreds of thousands of Celestials. No wonder, then, that Dzungaria has not produced large cities and cultivated areas, and that her atmosphere is still one of unrest.

The land, as a whole, is a great lowland, as compared with the rest of Mongolia. Her average altitude is about 1500 feet, rising to about 4000 feet on the east, and dropping to 700 feet at the Dznngarian gate in the west, whilst the border ranges on the south rise to over 20,000 feet. Her waters run, except for a few self-contained basins, to the Balkash or the Arctic by way of the Ob-Irtish waterway. These plains are bounded on the north-east by the great Altai, and on the south by the Tian Shan, whilst they are cut off on the north from the Siberian plain by the Ala-tau, Barlik, and Sair ranges. Eastwards the steppes rise gradually and merge into the Gobi, through a narrow strait of about 130 miles, which here exists between the Altai and Tian Shan. Although thus shut in by mountains, through Dzungaria lies the open roads between China and Siberia, the only gaps in the frontier mountain wall. There are two well-marked outlets to the north for trade and transport. Between the Ala-tau and Barlik mountains lies the so-called Dzungarian Gate-a narrow trench of 10 miles in width, between the mountain walls on either hand. Further to the east lies the Black Irtish, which drains the south Altai to the far Arctic ocean.

These regions of Dzungaria are now fairly well mapped. New ground alone remains on the south-eastern border ranges-the Bogdo-ola, Bar-Kul, and Karlik Tagh. Although we traversed over some 3000 miles of country, on plain and mountain, we actually made addition to the map only in the extreme south-east. Here our work joined in with the survey made by Dr. Aurel Stein and his assistant, R. B. Lal Singh, and with the maps of Potanin and Kozlef, made respectively in 1876-77 and 1895.

A certain amount has been written and much conjectured as to the probability of the "overlapping" of the Altai and Tian Shan mountain systems in the ranges of Barkul and Hami. These ranges, which form the eastern extension of the Tian Shan, under the name of the Bar-Kul and Karlik Tagh mountain, obviously belong, orographically, to the Tian Shan. Yet when we come to examine their flora and fauna, we find a similarity between them and the Altai. After a continuous stretch of 1300 miles, from Tashkent to Guchen, the extensive Tian-shan system drops its crest and lays itself out into a rolling plateau. It was on reaching this area that Miller and I, in February, 1911, first started our work of surveying what was to include the entire group of the Bar-Kul and Karlik Tagh mountains.

We had travelled along the weary Pe-lu or northern high-road, which runs the length of the Tian Shan on the Dzungarian side, a trek of no enjoyment and much discomfort, experienced as it was in mid-winter.

No. VI.-JUNE, 1912.] 
We had passed in succession Manas, Urumchi, and Guchen, Chinese towns of some importance. At Guchen we reached the limits of the exhaustive exploration carried ont by Prof. Merzbacher in the ranges to the south. Consequently we started our survey and carried them eastwards to the limits of the mountains and to the edge of the Great Gobi.

A word as to our forerunners in these regions. In 1875 the Russians, Sossnowsky and Matoussowsky, passed across the ranges from Hami to Bar-Kul, and thence to Guchen, whilst on a journey from China to Siberia. Later the well-known pioneer Potanin visited Hami, and gave us the first idea of the geography of this district. The naturalists GroumGrjimailo, in 1889-91, recorded their ideas of the orography of this extremity of the Tian Shan. And, lastly, Kosloff gave us, as a result of his journey in 1893-95, the most recent maps of Karlik Tagh as a whole. In $1887 \mathrm{Sir}$ Francis Younghusband, in the course of a trans-continental journey from T'ekin to India, came down to the Karlik Tagh from the northeast, and crossed the passes to Hami. In the samo year Col. Mark Bell reached Hami from the soutb, and passing through Bar-Kul on his way to Urumchi was the only Englishman in advance of us to visit that town. $\mathrm{He}$ is the only Englishman to give us any account of this region.* Quite recently (1907) Dr. Stein's surveyor skirted the south side of the ranges to the north of Hami, and on to his maps we have worked in our own surveys. The material we collected on our journey has enabled us to bring out a detailed map of the whole region. We have not only endeavoured to show the exact land relief, but also the style of cruntry, the cultivated areas, pasturages, forests, and population. We have also been able to draw lines of demarcation where we suppose the limits of the Altai flora and fauna to be located.

On March 1, 1911, we crossed from the Pe-lu, the northern high-road, to the Nan-lu, on the southern side of the Tian Shan. The route took us across the above-mentioned plateau, where the Bogdc-olu mountains merge into the Bar-Kul range. It was winter, and snow lay deep in places. The plateau reached 5000 feet at the pass, but there were summits which reached to 8000 feet. On dropping down into the southern side, of course, we entered a warmer and dryer clime. Here the landscape was marked by excessive desiccation. It was in the small isolated basin of Chi-kuching that, for the first time in our journey across Asia, we really met with those most marked signs of a changing climate, namely, dead and dying poplar forests and tamarisk mounds of a great height.

A few days later we sighted the oasis of Hami and Kumul, and got our first view of the extensive snow-capped summits of the Karlik Tagh. This solitary group of snow-capped mountains, with peculiar table-topped summits on the west and with lofty tooth-like pinnacles and jagged peaks

* Since writing this paper, Dr. Aurel Stein's volumes, 'Ruins on Desert Cathay,' have been published, in which he gives an account of his visit to Toruk and Ara'tam on the southern edge of the Karlik Tagh. 
on the east, broken with well-worn razor-edged edges, splintered precipices, and deep-cut valleys, formed a strange contrast to the smooth stretches of Gobi below. An isolated group of snow-pinnacles tossed to a height of 14,000 feet, standing sentinel on the western edge of the Shamo. Such was our first impression of the Karlik Tagh-that far-removed and little-known mountain mass, where men live almost hermit-like lives, cut off from the outside world, separated even from those centres of human life that one finds dotted here and there over the immense wastes of Central Asia and Mongolia.

It was early spring when we first sighted the Karlik Tagh, and the abundant snow that lay over the high flat summits and spread themselves out into smooth wave-like fields, gave an enchantment to the somewhat barren plains of dust and stone that led up to the little oasis of Kumul. On a clear day the view from Hami is inspiring. Southwards stretch the yellow deserts to the fabulous Lake Toli, and still further away to China proper. Northwards rises the snow-ridge of the Bar-Kul range, linking up with the Karlik Tagh, which runs eastwards till lost to sight. A few fine summits rise from the centre of the Karlik Tagh, and at this date the snow-fields were very extensive on the plateau-like tops of the western end. Around us lay the little oasis and town of Kumal, with its walled Chinese city, its bazarrs and gardens. Further to the south lay the native Turki town, above which rose, from a eommanding position, the great mud palace of the khan or "Wang"-hereditary prince of the Khuauliks, Tsing Wang,-or prince of the first rank.

Kumul itself lies in a salt-encrusted plain, below the snowy crests of the Karlik Tagh, a veritable Garden of Eden in the midst of a howling wilderness. The water from the mountain torrents, sinking below the surface in the Piedmont slopes, on reaching the open plain, appears again at Kumul in the form of copions springs, which ooze up and form the irrigation supply of the oasis. The zone of cultivation and the inhabited area is very small, and only extends for about 7 miles north and south, and i) miles east and west, but such is the richness of the soil, and with such care is the ground terraced and watered, that it supports a large Turki and Chinese population. In the centre lies the town of Kamul, remnant of an ancient Mussulman kingdom, and the most eastern stronghold of Islam. Close beside, is the walled Chinese town, to whose Emperor the Prince of Kumul has held allegiance for 200 years. The native inhabitants are of Turki stock, descendant of the old Uigur peoples, now distinguished as Taranchi, Chanto or, more exactly, Kumuliks.

Long ago (1513) Kumul was an integral part of the Uigur Khanate of Turfan, but in 1669 it became Chinese. During the Dungan rebellion the oasis suffered much at the hands of the Mohammedan destroyers (for the Turki and Chinese Mohammedans fell out amongst themselves), but since the re-establishment of Chinese rule it has recovered its prosperity. Kumul presents many interesting studies. The strange mixture of Islam 
and Buddhism, Turki and Chinese, gives rise to many peculiarities and customs, whilst the position the oasis holds on the main route between east and west makes it a refuge for desert-worn caravans. It has some importance also from the point of view of trade and transport, between China proper and Sinkiang, the new dominion. In point of fact, Kumul is the capital of a protected native state and the residence of its khan. The Mussulman town itself, and the scattered hamlets situated round the Karlik Tagh, together with several villages on the south side of the Bar-Kul range -as far west as Lodun, all owe allegiance to the khan. It would be difficult to give an estimate of the population. We have a knowledge of thirty villages under the khan, which supply a total of about 1000 or 1200 houses. Kozloff gives the population of the Taghliks or mountaineers at 500 families.

The khan resides in a somewhat quaint structure, a mixture of Chinese and Turki architecture, where he keeps up considerable state. As a vassal of the Emperor of China he visits Pekin every sixth year, where he acts as personal servant to the Emperor for forty days, as a sign of his allegiance. Treated with respect and honour by the Chinese, in acceptance of 2000 saires a year, besides twenty-five bales of silk, etc., with his people in comparative serfdom, he has a pretty good time of it, and is presumably very wealthy. He has, in fact, the status of a mediæval English baron, and lives in a somewhat similar style. From what we could gather, the prince appeared to be more feared than liked, and he was by no means popular. We noticed general discontent amongst his subjects, even here in this back corner of the world there was a desire for freedom from an autocratic rule. His subjects were eager to become directly under Chinese rule, being already Chinese in everything but name and religion; but they have noither the initiative nor the enterprise to make a step in this direction. The man that has "ideas " is exiled, and we met many such in the outlying villages at the furthest corners of his dominion. We found, too, that all the hunters had been deprived of their guns, forfeited because of an attempted rebellion last year. If Kumul was nearer the Russian frontier, she would no doubt desire Russian protection, in the same way as at the present moment the Mongols and the Kalmuks of Western Dzungaria are endeavouring to escape the yoke of China. The khan owns much private land and great flocks of sheep. The land is tilled, sown, and harvested, and herds are cared for by forced labour.

The Wang, however, treated us with all kindness and honour. The English, he said, were friends of Islam, and he was always glad to meet them. Hindustan he knew of, and, being a Mussulman of the strictest type, he appreciated the foreign rulers who respected the religion of their subjects. The fact of this extremely strict Mussulman community situated at the very end of the Islamic world, and yet completely under Chinese infuence, is indeed a paradox. Herein lies the chief peculiarity of Kumul. 
It is cut off from any other stronghold of Islam, and ontside the sphere of influence that might go to keep its religion pure. Few Mohammedan strangers pass through it, and it is situated amongst Buddhists and Chinese, without a faith. Moreover, it has been so influenced by Chinese elements during the last two hundred years as to have adopted its dress, to speak its language, and even in many cases to eat Chinese food. Yet, in spite of this, the Kumuliks present a type of Mohammedan people that it would be hard to beat for strictness and the exact keeping of the letter of the law. This, no doubt, is partly due to the khan's eagerness to keep his people from becoming contaminated by the Chinese, realizing that by this he would lose his hold over his subjects. So he strictly enforces the tenets of the Mussulman faith; men have to pray whether they like it or not, and for offenders large whips are kept hung in the courtyard of the castle, and used without mercy. The drinking of spirits is forbidden, and morality is a feature. A strange antithesis-indeed, a moral town in Chinese Turkestan.

The prince lived in a Chinese house, he gave us a Chinese dinner, he and all his servants were in Chinese dress and wore mock pigtails. On the other hand, he would scarcely drink from a bottle of spirits he opened in our honour, and went out halfway through the dinner to pray at the mosque.

We found the Turki town to be a rabbit-warren of a place between high mud walls. It presented a harvest of pictures to the artist, with its narrow alleys, overshadowed by fine old trees, its little mosques, and groups of gaudily dressed women. The latter we stalked with our cameras without much success. Shy as rabbits, they dived into their houses when they saw us approaching, and even locked the doors until we were well past. Overlooking the town is the pile of buildings making up the khan's residence, picturesque in its possession of several storeys, high walls, great gateways, and a paved road leading up to it. Here in Eastern luxury lived the khan, surrounded by his retainers and courtiers, with stables for his horses, mews for his falcons, and a high three-storied harem for his womenfolk. Around the palace was spread a garden of extraordinary luxuriance. Here amongst orchards and flower gardens were built miniature temples and summer-houses, even a shootingrange found a place, where the archers might practise. There was an artificial lake, where, on an isiand in the midst of iris beds and under the shadow of great trees, was planted a cool pavilion. The garden of the Khan of Kumul was a paradise, scarcely excelled outside the 'Arabian Nights.'

The water which drains southwards from Karlik Tagh is for the most part lost below the surface of. the ground after leaving the mountain. No existing maps give a true idea of the drainage. Blue rivers, flowing strongly out into the waste where they form lakes (kul), are common errors of the maps. As a matter of fact, what water escapes use for 
irrigating purposes disappears below the surface of the ground. In a few cases it reappears as small springs in some depression in the desert, when there is a sufficient supply from the mountains to feed them.

The river that creates Hami, for instance, disappears a mile from the point where it leaves the rugged granite foothills of the Karlik Tagh; 18 miles further on five large springs appear in what was once its riverbed. This water is used for irrigating the oasis. Twenty miles below Kumul the water is bad and too salt for irrigation. Beyond this there is no continuous flow of water. In summer when the snow melts in the ranges there may be a continuous flow above ground to the lakes, as marked in the Russian maps as existing to the west. But this would only be for a short period. I think these lakes are merely formed by springs of varying abundance.

The illusive problem of Lake Toli, that imaginary patch of blue in the north-eastern deserts of Chinese Turkestan, has long attracted my attention. From information I gathered, my explanation of the so-called lake is as follows :-

The Kumuliks have a somewhat different rendering for the Turki words relating to water, and the words they use for springs, lakes, rivers, etc., are of some importance. Theirs is a very exact interpretation. A river is only a "daria" for a short time in spring, when the watercourses are full. They only speak of "daria" when the melted snows from the mountains come in high flood across the plains. The remainder of the year the water-supply is called "bulak" (spring). Any ordinary watersupply is called "bulak," even good-sized streams used for irrigation purposes are "bulak," because they originate from springs and are not continuous from the snows. This is, of course, exactly the character of Karlik Tagh rivers.

Now, a large group of strong springs is invariably called "kul," a word like "Nor" being generally used to denote a lake or large sheet of water. There is Iti kul near Togucha, Shona Nor at the end of the Hami river, and Toli kul in the desert to the south. I believe this caused the early explorers to locate lakes, by hearsay, in a region where only springs really existed. It is not too much to suppose that Toli kul is, in reality, a depression in which, if there was water enough, there would be a lake. But as a matter of fact there is only a meagre supply of water issuing from underground, the remnant of the Karlik Tagh drainage. It is never sufficient in itself to form a lake; nevertheless, according to the Kumulik idea, it is a "kul." No dcubt, once there was a lake. An old trade route led thence from Hami, and on across what is the most inhospitable desert, to join the great trade route that runs between $\mathrm{Su}$ Chow and Lop Nor.

By command of the khan, men and horses were provided for us, and such orders were given as would enable us to travel at our pleasure and see the whole of his territory. Relays of horses took us wherever our work led us, whilst our heavy baggage went by cart, along the plain at the 
foot of the mountains. In this manner we traversed the whole of the Karlik Tagh, until leaving the territory of the Wang at Bar-Kul. By penetrating to its uppermost valleys and clambering transversely (with no small amount of difficulty) over its granite ranges, we made maps and got a rare insight into the conditions of life in this insular mountain mass.

North of Hami and at a distance of 20 miles lies the Bar-Kul range, running west and east, in a narrow even ridge. Due north of the town, where this range merges into the Karlik Tagh, there are cols of about 8000 feet altitude, over which tracks lead to the town of Bar-Kul. Eastwards of this lies a peculiar block-shaped range of flat-topped ridges and deep-cut ravines, which gradually breaks up and falls off into excessively rough country in the extreme east.

A peculiar feature is the outlying range of granite, which makes travelling exceedingly laborious, and which confines the native population and their cultivatable area to secluded valleys between the ontlying granite and the main range. In fact, the rivers invariably pass through this granite wall by deep-cut ravines, and the lower valleys give no access to the rupper. The valley of the Bardash, situated in the central portion of the range, is typical of the whole southern side, and I may as well give my impressions of the contrastive features of the country as they came to me. Leaving the plain, we faced the abrupt wall of outlying granite that forms the first foothills. For some hours we toiled painfully over barren, red ridges, destitute of everything but thorn scrub. The river-valley itself was not negotiable; the stream wound through a steep side ravine, which allowed no space for a track. Occasionally from the crest of a ridge we got a view of some peaks ahead, and of the immeasurable desert that lay below and behind us. But later we dropped down into the main valley, and after passing through thickets of rose and willow, under gigantic elms, poplars, and walnuts, we came to where the valley floor was wirle and open, and men had room to cultivate.

In these secluded upper valleys the "Taghliks," or "mountaineers," live a peaceful existence. Most valleys support but one village, generally situated, as Bardash is, at the back of the granite range. Only in the Narin valley, where the rivers unite before breaking through the outer range, is there a considerable group of villages. Very often we came across isolated groups of three or four farms located in some place where the nature of the country allowed a small area of cultivation. Every available patch of ground was made use of, and I do not believe there is a spare acre on the mountains. With an increasing population, the available land does not increase, and since the khan forbids emigration, there is "overcrowding" in the pleasant valleys of the Snowy mountains.

After the impoverished aspect of the plains these high valleys seemed pleasant enough. We rode through fields which had been cleared-with infinite labour-of rocks. Chukor and brown partridges called from the 
rocks above, and small boys, herding the flocks of goats, sang more joyous songs in their mountain home than their confrères of the melancholy plains. Pleasantly situated, too, were their houses of stone and mud, which are as often as not perched on the rocks so as to avoid wasting the land capable of cultivation. In no less a degree did the people attract us. They were essentially " mountain-folk," and we could trace their likeness to the Tajik mountaineers of Bokhara and Hunsa, rather than to the lethargic Chantos of the Turkestan plains. Their life, too, is harder. Only small patches of ground are available for cultivation, and these have to be cleared of rocks before ploughing is possible. The men were well made, clad in half-Chinese, half-Turki costames, and wearing mocassins over thick felt stockings. The women, too, were freer here than their friends " in town," and behaved with a natural inquisitiveness and freedom which was denied to the Kumulik ladies. Bardash was, in old days, a summer resort of the reigning khan. His "shooting-box," a show-place to visitors like ourselves, is built in Chinese style in a beautiful orchard of fruit trees, and surrounded by some fine walnuts. But it has fallen into disrepair, for the present khan is too old to accomplish the journey to this mountain village.

The valley of Bardash is isolated, and in order to reach another, one must noeds toil over rough transverse ridges for a day's journey. We followed most of these valleys up to their sources, which in all cases rose in glaciers of varying sizes. The Bardash valley, which drains from the highest peaks, held a glacier of about a mile and a half in length, and showed old moraines for a distance of 5 to 6 miles below the present snout of the glacier, which reach to within 3 miles of the village of Bagdash.

From summits of 12,000 and 13,000 feet at the eastern end of the range we got views which repaid us for the extraordinarily rough climbing that this entailed. At these points of vantage, within sight of herds of ibex and the call of snowcock, we could lcok out over the whole of desert Cathay, and it was easy to grasp the essential features of the land to the east and south. We noted the peculiar table-like tops of the western portion of the range, and the excessively steep and broken country at the east end, with its razor-backed ridges and V-shaped valleys. We gazed out over the ocean-like desert that washes up to the very foothills of this insular mountain mass. On a clear day in winter or early spring, before the summer heat-haze begins to hide the distance, and when no south wind with its complement of "loess" darkens the air, you may stand aloft on some pinnacle of the Karlik-Tagh ard gaze, till the eyes ache, over immeasurable distance. You can search the southern deserts, where yellow flats reach unending to a far horizon, only broken here and there by pyramidal hills of carmine and yellow ochre. Eastwards the gaze is mystified by the regions of colour that are shown by the succeding ranges of desert hills, as they pass from yellow to dun, and to purples, till they reach the softest ultramarine, and fade into distance at 100-miles range. Still one has surveyed but half the panorama. Northwards alone is the horizon 
broken by far-distant snow ranges-the great Altai. These stand up superbly, and their height is intensified by the desert gap in between. There wander the nomad Mongols-a different world altogether to this settled region of Chanto farm and Kumulik hamlet.

Though narrow, deep-cut valleys open up beautiful vistas of larch and pine forest; for, curiously enough, the extreme eastern end attracts, for some reason, a considerable rainfall, and the valleys are well forested. Settlements of Kumuliks are here few and far between. A few, such as at Bai and Nom, exist, as the last examples of sedentary life on the edge of the great waste of Gobi, or the Nomad's land of Mongolia. Within our view we held the limits of four different Asiatic peoples. On the north ranged the Kirei Kasak and the Mongol hordes, whose territory we could just discern. Eastwards, across an intervening zone of uninhabited desert, rose the isolated Ati-bogdo range, the summer quarters of Torgut Mongols from the Edsin-gol lake, in the very heart of the Gobi. Southwards stretched the interminable desert to the Hoang Ho and the gates of China proper; and over it comes the ceaseless, plodding bands of tenacious Chinese.

The region between Karlik Tagh, Ain-si, and Su-chow is highland; it averages over 5000 feet in altitude, and supports Chinese settlers in small isolated communities. They come right up to the border of the territory of the Khan of Kumul, and at one place, Tash Bulak, they have supplanted the Kumuliks.

The northern side of Karlik Tagh differs from the southern, in that it is a fine pasture land. On the north the snowfields run down to a rolling plateau of about 10,000 feet, and this leads down at a gentle grade to the desert below. From 10,000 feet down to 7000 feet extends fine upland pastures covered with rich grass, which compare strongly with the barren, desiccated rock area of the southern slopes. Here, in consequence, the Taghliks have adopted a semi-nomadic existence and live chiefly in yurts, of the ordinary type. But the movable tents presented a half-fixed appearance, for there were kraals for the herds built close by, and, as often as not, a hedge of scrub and grass for protection from the wind. Now and then we came across great flocks of sheep, which we found in most cases belonged to the khan. But the accessibilities of these open grazing grounds hinders them from being reserved as private pastures for subjects of the khan; in consequence, Chinese herdsmen from Bar-Kul use them considerably.

The scenery here is varied by the presence of two lake-basins, namely, Tur-Kul and Bar-Kul. The former is a small upland basin at an altitade of 5 . 800 feet, bordered by high ranges on the north and south, but apparently once draining through on the west to Bar-Kul. The lake is exceedingly salt, but excellent pastures border it where the ground is wet and boggy.* We chanced to be there during a spell of bad stormy

* An analysis of water from the lagoons of Tur-Kul shows that it contains 34 per cent. salt. For comparison, I might mention that the water of the Dead sea contains 25 per cent. The water of Bar-Kul contains 3 per cent. 
weather, and the lake was alive with myriads of wildfowl, which had songht refuge there from the more exposed waters of Bar-Kul.

The wide plateau basin of Bar-Kul is, however, the real feature of the northern steppes. I shall not forget my first impression. A wild sunset hung over the forested Bar-Kul range; the grassy steppe was dotted with cattle, herds of horses, and the black yorts of the shepherds ; small farmsteads gave an air of settlement. Northwards arose the height of Mechin-ola, flat topped and rough sided. It was an animated scene for Central Asia; it was as if one had at last found an Eldorado, free from the blight of desiccation. The largest forest we saw existed here on the northern slopes of the Bar-Kul ridge, the pleasantest temperature warmed us after the cold of the bleak plateaus, and the finest horses ran balf wild in great droves over the prairies. Besides the black yurts of the shepherds, there was a considerable element of sedentary life. Chinese colonists had here taken up large areas of land for corn growing.

In connection with the adjacent pasturages and cornlands Bar-Kul itself is an important centre. Situated close under the mountains, where spruce forests abound and where melting snows perennially saturate the surrounding country and keep the pastures fresh and green throughout the summer's heat, it forms the centre of trade for the surrounding country. Here come the Kumulik shepherds and the Chinese farmers, who find in the bazaars what little they need in the way of food-stuffs and clothing. You may here meet Kalkas from the northern Gobi, caravaners from far Cathay, and Chanto merchants from the great oasis of Eastern Turkestan. But Bar-Kul does not possess a good reputation, in spite of its numerous places of worship (there are said to be from eighty to one hundred), and this in a town of but about five thousand inhabitants. Its bad reputation has had, I expect, something to do with it having been avoided by so many travellers. Prjevalsky passed close by, but did not enter; Atkinson approached from the north within sight, and then swung back again into the desert; Younghusband passed it to the enst and went on to Hami. We were even told that the caravans from Koto-Koto, on the banks of the Yellow river, nsed to include Bar-Kul in their itinerary, but now they go direct to Guchen by the desert route, in preference to risking trouble at Bar-Kul. This, in a region where towns and bazaars are so scarce, is remarkable.

The feature, par excellence, of Bar-Kul is its horses. We harl always been puzzled as to the kind of animal which had given the name to "Bar-Kul," or "Wild animal lake." Certainly, its neighbourhood possesses abundant animal and bird life. We saw wildfowl innumerable on the lake, and its western shore is the haunt of troops of gazelle and droves of wild asses. But, we think, the real "wild beasts" of the Bar-Kul basin are the great herds of unridable horses---the broncos which run half wild over the surrounding steppes. To the number of fifteen thousand these horses form an Imperial stud, the pick of which are taken every year to Pekin. 
Although Bar-Kul has only been founded about two hundred years, yet it possesses some antiquities of very great interest. The black stone called Tzin-Chen-Bei, for instance, which we took squeezes of, has a reputation throughout China. It records the victories of a Chinese (Mongol ?) general, and is preserved with care in the precincts of a temple.*

On leaving the Bar-Kul we journeyed again in the deserts of the southwestern portion of Dzungaria, and from our studies of the fauna of these regicns and the Karlik Tagh we have mapped out the various distributions of the different species of mammals, both large and small. As a result, we find this particular district is a sort of neutral ground between different well-marked zoological areas. Species, typical of Siberia, Mongolia, and Turkestan, here meet and overlap. The Saiga of the steppes of Russia and West Siberia ranges up to the edge of the Mongolian plateau, just north-west of Bar-Kul. The wild horse of Mongolia meets the range of the Saiga. The wild sheep of the Karlik Tagh is of a species peculiar to the Tian Shan, and it is the same case with the wapiti, ibex, roe-deer, snowcock, and partridge. Across the gap of 130 miles these species can see the haunts in the Altai of their cousins of a slightly different variety. The presence of larch forest give the Karlik Tagh the aspect of Altai scenery, and the existence of numerous little picas, or tail-less hares, and molerats (Ellobius) of species closely allied to those of the Altai system, show the affinities that this range has to the Altai. But there is a limitation to this in a hard-and-fast line across the Chi-Ku-Ching platean, which defines the end of the -neutral zone and the beginning of the Tian Shan flora and fauna.

In retracing our steps westwards from Bar-Kul we traversed again the whole length of southern Dzungaria. Being spring, the country presented a very different appearance to what it did in midwinter. Flower's now

* The Bar-Kul basin is the possessor of one remarkable physical feature, which amounts almost to a phenomenon. It should be understood that the entire floor of the basin is more or less saturated with water, and in consequence cultivation is possible. Nowhere does it present features such as sand-desert or tamarisk mounds, which exist in any other part of Dzungaria and Chinese Turkestan. It is an upland basin into which is drained a considerable amount of water every year, chiefly from the snow-clad ranges on the south. It does not present the appearance of a desiccated area. Yet at the extreme eastern end of the basin, isolated between the gaps that lead to Tur-Kul and over to Hami, there is a remarkable group of sand-dunes. They cover only a small area of 5 or 6 square miles, but attain a great height.

Neither in the sand-areas of Dzungaria nor in Chinese Turkestan, nor even in the great sand-belt of Transcaspia have we seen dunes of the height of these. Mr. Miller, who spent some time in the dunes, reckoned the maximum height to be 400 feet. The dunes were very curiously formed; a profile of their summits showed a sharp angle instead of having the long-back windward side and sharp drop-off in the leeward. In the centre of the dunes was a regular "falj," or circular pit, which went down to the floor of the plateau, and supported vegetation in the shape of grass and scrub. Here, according to native report, is a sand-buried Mongol village. At nights, they say, can be heard the crowing of cocks and the lowing of cattle. 
carpeted the steppe in place of unbroken snowfields. And the country, which in January had seemed to be lifeless, appeared now the home of thriving colonists, and showed as well signs of much undeveloped land. In choosing Dzungaria as the locality for the Government centre of all the New Dominion, the Chinese did well. Here aloue was there ample room for settlers, and considerable areas fit for colonization. The numerous rivers which flow northwards from the Tian Shan and lose themselves in the sands of Central Dzungaria, were all running to waste. In spite of the large importation of Dungan immigrants, there is still ample room. Yearly there is quite an influx of Chinese to Dzungaria and the Ili valley. Chantos, too, come over from Chinese Turkestan, where all available land has for long been taken up, and taxed to the limits of its capabilities.

Southern Dzungaria, then, assumes the appearance of a new colony. Of towns there is Urumchi, the capital of all Sin-Kiang; Manas, the great agricultural centre; and Guchen, the terminus of overland traffic between Dzungaria and the Yellow river. Apart from these towns and other scattered villages along the Chinese Imperial high-road, there are only two other settlements. On the northern frontiers there is Chuguchak, consisting of a walled Chinese city and a good bazaar supported by Tartar, Russian, and Turki people. Far away on the southern slopes of the Altai is the new town of Tulta or Sharasumé, which the Chinese are intending to make a strong frontier post. 'The rest of the Dzungarian lowlands are steppe, varied by pasture-land and areas of sand-dunes, the whole sparsely populated by Kalmuk and Kazak nomads. The rivers which flow from the Tian Shan and Ala-tau are in every way like those of Chinese Turkestan. Their banks are forested with poplar and jungle, but nowhere did we find these forests suffering from desiccation to the degree in which they are found on the southern side of the mouritains. The aridity which marks Chinese Turkestan does not extend to Dzungaria.

Nevertheless, we experienced considerable difficulties in an attempt to cross the plains, early in June from Manas, north-westwards, to the Barlik regions. The nature of the ground was, over large areas, a soft saltencrusted plain of friable earth, most tedious to man and beast. Where water approached the surface, dangerously soft ground bogged the horses and made progress slow, and to travel transversely to the waterways entailed heart-breaking détours, to get across the deep-cut gorges which have been carved out by the streams. Sometimes without water, and at others tortured by myriads of most vicious mosquitoes, travelling by night and pretending to rest by day, we at length reached the happier pastures of the Barlik mountains, and later in the summer visited the uppermost reaches of the Borotala valley. These pleasant lands are the home of innumerable nomads. Kasaks, a branch of the Kirei clan, hold tise Barlik and Jair ranges, but the whole of the Borotala we found to be a reservation for the Charkhar Mongols.

The plains of Dzungaria are of complex character. They are, for the 
most part, a hard dry steppe, with scanty vegetation. This is varied by areas of sand-dunes; the largest of these sand-belts occupies an area of about 10,000 square miles, and is situated in the heart of the country. (Prjevalsky crossed its widest extent.) Saxaul and tamarisk generally cover the sand regions, and these are often a winter resort for the Kazak nomads, who use snow for drinking purposes in what is a waterless tract for the rest of the year.

Along the southern border under the Tian Shan range, one finds a zone of vegetation where the water from the mountains approaches the surface; this is generally about 20 miles from the foot of the mountains. Further away the water is lost except where it runs in such channels as the Manas river, and then it reaches out across the whole width of Dzungaria until lost by evaporation in the Telli Nor.

In the zone of regetation are situated the Chinese, Dungan, and 'Taranchi settlements. Of these three, the Dungans, no doubt, possess the greatest inter'est, ethnographically and politically. Of the origin of these Chinese Mohammedans, who can say? 'Theirs has been called "the most obscure problem in Asiatic history." Some suppose them to be a remnant of the ancient Uigurs, who in early days emigrated from the north to the provinces of Kansu and Shensi, and became Chinese in everything but religion and character. Others believe that they originally came from Samarkand. There are no records of them. Suddenly we find them established in China as strongly as they are to-day. The Dungan colonies of Dzungaria date from early in the nineteenth century. Slowly these active and ambitious people got the upper hand, till at last their hatred of the Chinese led to the rebellion and massacre of 1860-70. The Dungan remains a danger in far Western China. He is just as hostile to the Chinese as ever he was. $\mathrm{He}$ is virile, active, and superior to the Celestials in business matters; he is capable of great things.

Once off the floor of the Dzungarian plain, there is almost always to be found a zone of pasturage. These vary in excellence according to the position of the ranges; all the northern slopes are tenanted by nomads, but the southern slopes that face the deserts are generally very barren. Above this, one can delight in forests of spruce, rippling brooks, and flowerstrewn meadows, which are, as often as not, backed by the stainless snows of peaks that run up to 20,000 feet.

On the southern border ranges, the Bogdo-ola is the feature of all that part of Dzungaria. A solitary block, made up of three peaks, tossed to a height of over 17,000 feet, stands alone, and is to be seen from 100 miles distance in every direction. Prjevalsky saw it from the Altai at 160 miles, and we took bearings on to it from Ta-shi-to near the Bar-Kul range. Such a summit calls forth wonder from the superstitious natives; it is the "Olympus" of the Mongols. Close under it, in a steep-sided amphitheatre, is the esacred lake of Bogdo-olu, graphically described by a previous traveller as "the pearl of the Eastern Tian Shan." The report of the 
Bogdo-ola volcano resulted from the Chinese myth that fire and smoke issued out of it when the gods visited it once a year !

If the northern border ranges are less inspiring, nevertheless they are excellent country for the shepherds. The Maili and Barlik are well tenanted by a powerful tribe of Kazaks, and I believe the Jair, Urkashar, and Sair are, in like manner, well populated. But the "land of promise" of all Dzungaria is without doubt the Borotala. That long upland valley, enclosed on north and south by high ranges, holds out pleasant prospects to ranchers and colonists. It is envied by all, but reserved intact for the Charkhar Mongols, to whom it was given as a special privilege. The Charkhars' presence in this far western corner of the Chinese empire is an example of that innate habit of change which is the soul, the life, and the ordinary occupation of the Asiatic nomad. We, in these days of sedentary life, narrow conventionalities, and carefully delineated frontiers, can scarcely realize the magnitude of those movements in the old days. Formerly a conqueror thought nothing of shifting a whole nation across a continent, or of colonizing the lands he had laid waste by importing bands of captives. Now the world is too cramped and confined; carefully surveyed and jealously guarded frontiers forbid such excursions as were made by the Torguts, the Eleuths, and the Charkhars. A nation or even a tribe wosld find considerable obstacles in its way if it started to overrun Asia.

'The Charkhars were once a tribe of some account in South Mongolia, outside the Great Wall of China. Owing to their formidable numbers and warlike nature, the Chinese feared them, and at length broke their power and transported them in bulk to the furthermost western corner of the empire, and gave them the Borotala as a reservation. Here t'rey remain, and, if I mistake not, they are better off than in South Mongolia. For those "lands of high grass" are now being rapidly overrun by Chinese colonists, to the detriment of the few nomads that remain there.

The Borotala is an exceptional region, and gets an unusual amount of summer rain. Heavy forests, which extend all along the southern slopes of the Ala-tau, prove this, as does also the fact that the nomad Kalmuks can exist in excellent pastures all through the heat of summer at the low altitude of 2000 feet. It is a fine valley, well watered and timbered, and granting every possible scope for cultivation. The Charkhars abound in large encampments along the river-banks, and even a few Chanto and Chinese farmers have found a footing, by renting the land at an exorbitant price from the chiefs. They pay fifty per cent. of their produce. The upper portion of the valley and the higher ground on the bordering ranges supported large numbers of the Kho-ching section of the tribe. These were the original settlers, those of the lower parts being new-comers - Chi-ning. We noted the superior type of the Charkhars, in comparison to the Torguts. They were almost clean-looking, possessed some fine 
yurts, and appeared to be well-to-do. One is always struck by the paradox which thus presents itself, of a people at a standstill in a magnificent and pregnant land. There is land to waste in the Borotala; it would hold a far denser population, and only the fact of Chinese protection of the Mongol rights of ownership hinder the Kasaks from overrunning it. Yet the Kalmuks do not appear to increase. The Mohammedan Kazak is everywhere on the increase, and moving eastwards. There is a great flood of these nomads from the Russian territory always tending to overrun the Chinese preserves. They have done it in the Tekkes valley in the Tian Shan, and they are doing it in the Tarbogatai region. The Mohammedan is on the increase ; the Buddhist must give way.

On leaving the Borotala we passed out of the region we had made it our work to study. Later in the summer we crossed the Tian Shan by the well-known Muzart pass, and descended to the plains of Chinese Turkestan. Journeying with the sole object of getting home as quickly as possible, we passed to Aksu, Kashgar, and Yarkand. In October we bade farewell to the heart of Asia for the crest of the Karakorum pass, and in due course reached Leh, Srinagar, and Bombay.*

Sir Thomas Holdich, Vice-President (before the lecture): Mr. Douglas Carruthers, who is to address us to-night, is a young gentleman who has devoted nearly the whole of his time to scientific exploration. Some six years ago he was connected with an exploration of Mount Ruwenzori in Africa. In 1908 he was with Mr. Rickmer Rickmers in an exploration in Central Asia. In 1909 he undertook a most adventurous and what I consider a most risky journey in Northern Arabia, the results of which were communicated to the Society, and for which he was awarded the Gill Memorial. More lately, during the last two years, he has been engaged with two companions-Mr. Miller and Mr. Price-in exploring a region in Central Asia which is of particular interest to us in many ways, including the upper Yenesei basin and the Altai mountains, and the results of that journey he is going to tell us to-night. I wish you particularly to note the names of his companions, Mr. Miller and Mr. Price, because Mr. Carruthers informs me that not only is he indebted very much to these gentlemen for their assistance in scientific research, but they also bore on their shoulders a great part of the responsibility of financing the expedition. I think that Mr. Carruthers needs no further introduction by me, and I will ask him to commence his paper.

Sir Thomas Holdich (after the paper): We have listened to a paper which I think I may say in many respects is a model of what a geographical paper should be. It has been suggestive, instructive, and extremely interesting at the same time. But the suggestion in it which appeals to me most is that which touches a longforgotten phase of Central Asian history. You will remember that when the Nestorian Christians scattered eastwards about the middle of the fifth century they

* The botanical collections made by Mr. Price on this expedition are being worked out at Kew, and the geological specimens by the Geological Department of the British Museum. The entire zoclogical collection has been purchased by the trustees of the British Museum (Nat. Hist.). This consisted of 250 birds and 160 mammals; from the latter Mr. Oldfield Thomas has named 14 new species. Other zoological specimens, consisting of numerous species of the larger animals, were collected by $\mathrm{Mr}$. Miller, an account of which he is preparing for the Zoological Society. 


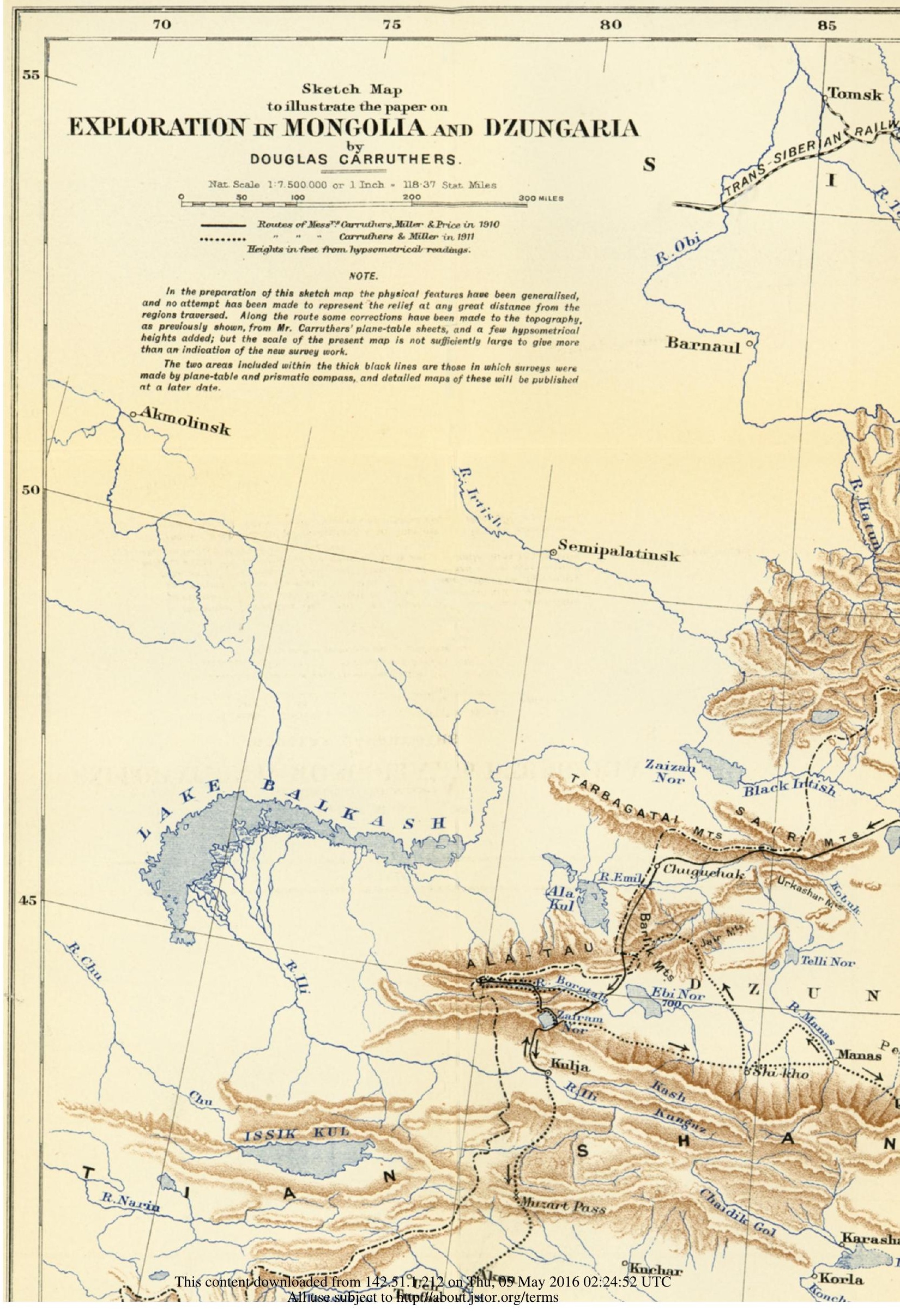




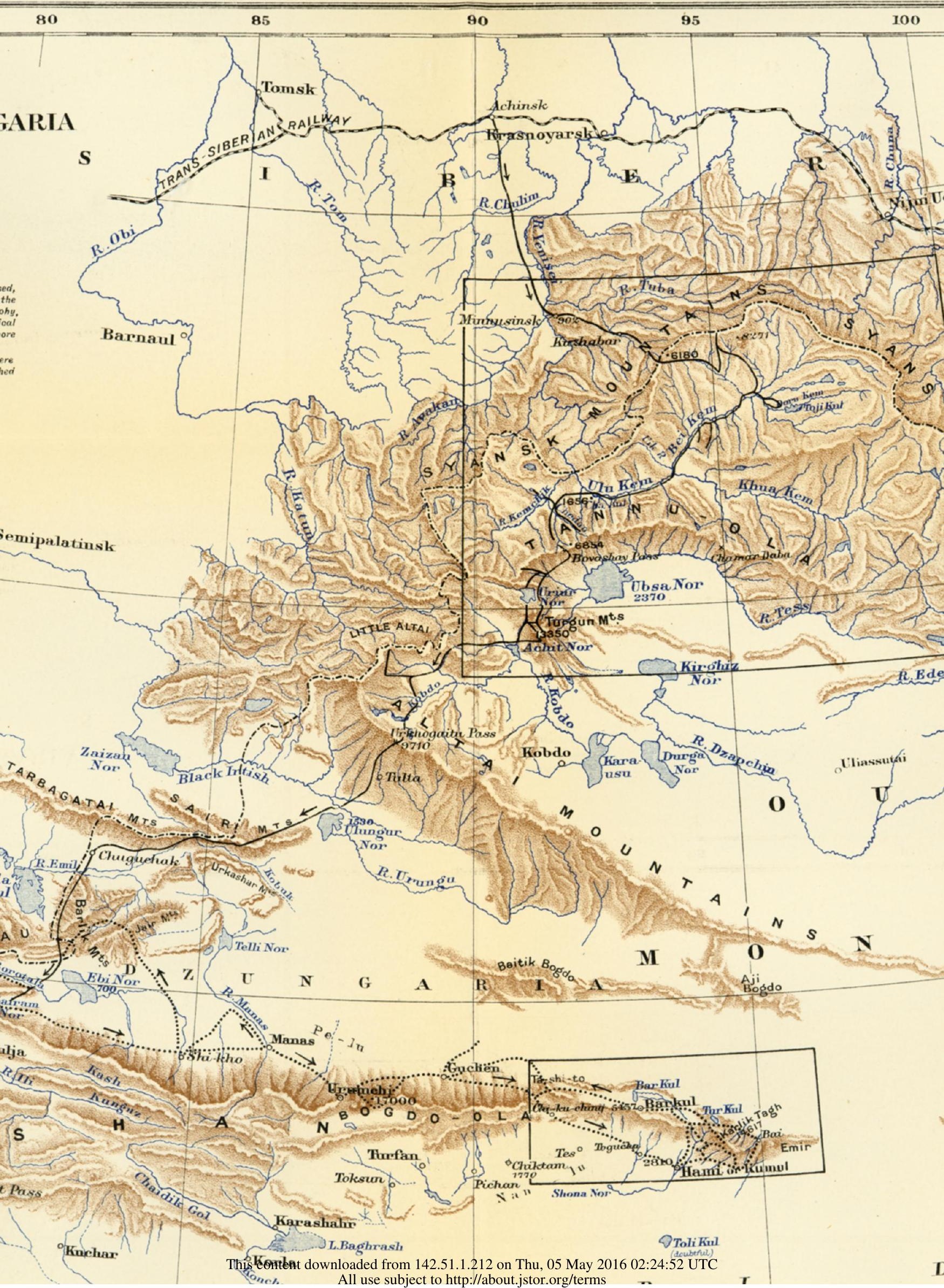




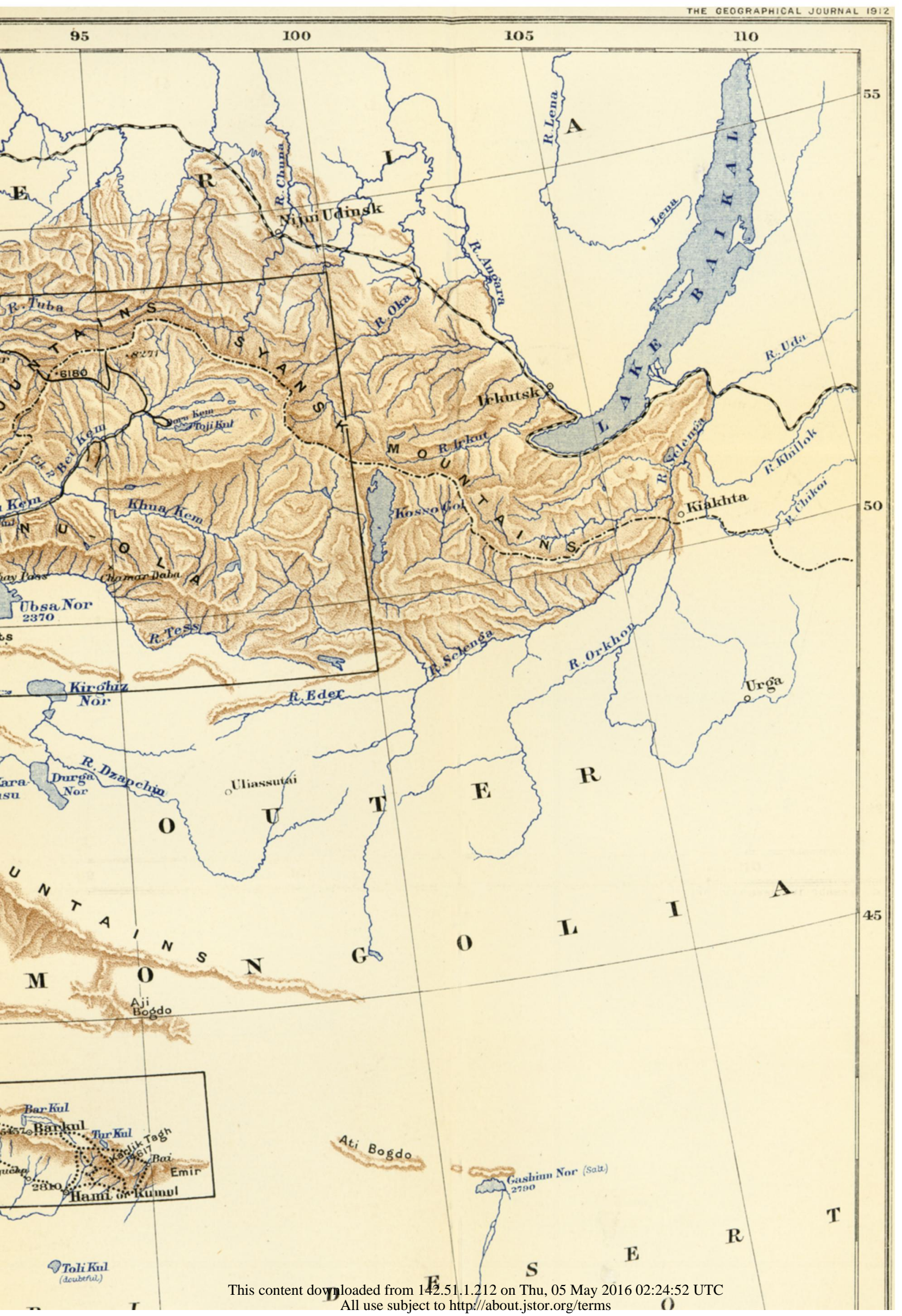



